\title{
Delphi Yöntemi Kullanarak Afet Sonrası Geçici Barınma Alanı Seçimi ve Planlaması Ölçütlerinin Belirlenmesi: İzmir/Seferihisar Örneği
}

\author{
Hande Dayanır ${ }^{1}$, Ali Kemal Çınar, ${ }^{2} \mathbb{D}$, Yenal Akgünn ${ }^{3}$, Özşen Çorumluoğlư ${ }^{\mathbb{D}}$ \\ ${ }^{1}$ Izmir Kâtip Çelebi Üniversitesi, Fen Bilimleri Enstitüsü, Kentsel Dönüşüm Anabilim Dalı, 35620, İzmir. \\ ${ }^{2}$ Çiğli Belediyesi, 35630, İzmir. \\ ${ }^{3}$ Yaşar Üniversitesi, Mimarlık Fakültesi, Mimarlık Bölümü, 35100, İzmir. \\ ${ }^{4}$ Izmir Kâtip Çelebi Üniversitesi, Mühendislik ve Mimarlık Fakültesi, Harita Mühendisliği Bölümü, 35620, İzmir.
}

\section{Özet}

Afet sonrası geçici barınma alanlarının gerekli ölçütlere uygun olarak yer seçimlerinin yapılması ve vaziyet planlarının tasarımı, afet ve risk yönetimi çalışmalarının en önemli konularındandır. Türkiye’de bu konu Afet ve Acil Durum Yönetim Başkanlığı (AFAD) tarafindan koordine edilmektedir. AFAD tarafindan 2015 yılında ilan edilen "Geçici Barınma Merkezlerinin Kurulması, Yönetilmesi ve İsletilmesi Hakkında Yönerge" ulusal ölçütleri büyük ölçüde tanımlasa da, uluslararası literatürdeki kadar detaylandırılmamış ve ölçütler önemlerine göre derecelendirilmemiştir. Ayrıca, AFAD tarafindan İzmir ili için önerilmiş olan afet sonrası geçici barınma alanlarının, ulusal ve uluslararası mevzuata ve literatürdeki çalışmalarda önerilen ölçütlere uygunluğunun değerlendirilmesi de bilinebildiği kadarıyla henüz yapılmamıştır. Bu kapsamda çalışmanın ilk amacı, afet sonrası geçici barınma alanlarının yer seçimi, planlama ve tasarımına dair ölçütlerin Delphi yöntemi kullanılarak derlenmesi, gruplanması, tanımlanması ve derecelendirilmesidir. Delphi yöntemi ile ortaya konan yer seçim-planlama ölçütleri listesi yardımıyla İzmir için önerilmiş olan afet sonrası geçici barınma alanlarının uygunluk analizinin yapılması çalıșmanın bir diğer amacıdır. Delphi yöntemi ile yapılan üç aşamalı panel sonucunda oluşan ölçütler listesine göre, İzmir'de sinırl sayıda alanın gereklilikleri karşılayabildiği tespit edilmişsir. Bu alanlardan biri olan Seferihisar2 alanının neden en uygun alan olduğu açıklanmış, yine Delphi yöntemi ile elde edilen tasarım-uygulama ölçütlerine dayanarak alan üzerinde örnek bir konteyner-kent vaziyet planı yapılmıştır.

\section{Anahtar Sözcükler}

Afet Sonrası Geçici Barınma Alanları, Delphi Yöntemi, Konteyner-kent Tasarımı

\section{Post-Disaster Temporary Shelter Area Selection and Planning by Using Delphi Method: Izmir/Seferihisar Case}

\begin{abstract}
Site selection of the post-disaster temporary shelter areas and their site plan designs constitute one of the most important issues of disaster and risk management studies. In Turkey, the Disaster and Emergency Management Presidency (AFAD) coordinates this research. Although the "Directive on the Establishment, Management and Operation of Temporary Shelter Centers" released by AFAD in 2015 mostly defines the national criteria, it is not as detailed as the regulations revealed in the international literature. Moreover, the criteria announced in this directive are not ranked according to their importance. As another important gap, convenience of the post-disaster temporary shelter areas suggested by AFAD for the province of Izmir has not been yet evaluated according to the national and international legislations. In order to meet these gaps, the first aim of this study is to compile, group, define and rank the criteria for the site selection and planning of post-disaster temporary shelter areas using Delphi method. The second aim of the study is to analyze the convenience of the post-disaster temporary shelter areas, which were suggested for Izmir by $A F A D$, using the site selection/planning criteria put forward by the Delphi method. According to the criteria list formed as a result of the three-stage Delphi panels, it has been determined that a limited number of areas in Izmir can meet the requirements. It has been explained why Seferihisar2, one of these areas, is the most suitable area, and a sample container-city site plan has been made on the area based on the design/implementation criteria obtained with the Delphi method.
\end{abstract}

$\underline{\text { Keywords }}$

Post-disaster Temporary Shelter Areas, Delphi Method, Container-city Design

\section{Giriş}

Dünya çapında her yıl binlerce insan doğal afetlerden etkilenmektedir. Yaşanan afetlerden sonra ortaya çıkan ihtiyaçlara bakıldığında barınma unsurunun -özellikle de afetzedelerin düzenlerini tekrar kurabilmeleri için güvenli barınma alanlarının sağlanmasının- afet yönetimi açısından öncelikli bir konu olduğu açıktır. 
Bu konu, Türkiye'nin de büyük çoğunluğunun, deprem başta olmak üzere, afet riski taşıması sebebiyle bizler için yaşamsal derecede önemli konuların başında gelmektedir. Türkiye'de afet ve risk yönetimine dair konular, Afet ve Acil Durum Yönetim Başkanlığı (AFAD) tarafından koordine edilmektedir. AFAD tarafından 04.11.2015'te yayımlanan “Geçici Barınma Merkezlerinin Kurulması, Yönetilmesi ve İşletilmesi Hakkında Yönergesi” (AFAD 2015) hâlihazırda geçici barınma alanlarının yer seçimi ve tasarımı konusunda Türkiye'deki en önemli kılavuz belge durumundadır. Yönergede belirli standartlar ortaya konsa da, yer seçim, planlama ve diğer ölçütler uluslararası literatürdeki kadar detaylandırılmamış, ölçütler önemlerine göre derecelendirilmemiştir. AFAD yönergesi dâhil, daha önceki araştırmalarda ele alınmış olan bir dizi ölçüt listesini Delphi yöntemiyle derleyerek bu eksikliğe cevap aramak bu çalışmanın motivasyonlarından biridir.

Ege Bölgesi ve İzmir il merkezinin kurulduğu alan, Türkiye'deki birçok bölge gibi depremsellik açısından oldukça risklidir. Tarih boyunca bu alan büyük depremlerden etkilenmiş, can kayıpları ve büyük yıkımlar ile karşılaşılmıştır. Özellikle günümüzde İzmir Körfezi kıyısında kalan ve il nüfusunun büyük çoğunluğunun yaşadığı ilçelerde, zemin etkisi ve yapısal problemlerden kaynaklı yüksek riskler halen sürmektedir. Bu riskler, 30 Ekim 2020 tarihinde İzmirSeferihisar Körfezi açıklarında gerçekleşen $\mathrm{Mw}=6.6$ büyüklüğündeki Ege Denizi Depremi ile kendisini tekrar göstermiş, afet yönetimi ve planlamasının önemini tekrar gündeme taşımıştır (AFAD 2020).

İzmir'de afet ve risk yönetimi çalışmalarını düzenlemek için AFAD tarafından 2019 yılında İzmir Afet Müdahale Planı (TAMP-İzmir) yayımlanmıştır. Bu plan kapsamında tüm ilçeler için “Afet Sonrası Toplanma Alanları" ilan edilmiş olmasına rağmen, "Afet Sonrası Geçici Barınma Alanları” bilinebildiği kadarıyla halen kesinleşmemiştir (AFAD 2019). Bu konudaki tek güncel çalışma, AFAD İzmir İyileştirme Şube Müdürlüğü uzmanlarınca yürütülmüş Geçici ve Acil Barınma Alanları (GABA) çalışmasıdır (AFAD 2017). GABA kapsamında önerilen afet sonrası geçici barınma alanları incelendiğinde, belirlenen alanların coğrafi ve altyapı özelliklerinin ulusal ve uluslararası ölçütlere göre kapsamlı bir şekilde analiz edilmediği görülmektedir. Bu çalışmanın diğer bir motivasyonu da literatürdeki bu eksiği doldurmaktır.

Özetlenecek olursa, bu çalışmanın ilk amacı afet sonrası geçici barınma alanlarının yer seçimi, planlama ve tasarımına dair AFAD ve çeşitli akademik çalışmalarca ortaya konmuş olan bir dizi ölçüt listesinin Delphi yöntemi kullanılarak derlenmesi, detaylandırılması ve derecelendirilmesidir. Çalışmanın ikinci amacı ise, Delphi yöntemi ile üç aşamalı bir çalışma sonunda ortaya çıkan ölçütler listesi yardımıyla İzmir için önerilmiş olan afet sonrası geçici barınma alanlarının yeterliliklerinin analiz edilmesidir.

Çalışmada Delphi yöntemi kullanılmıştır. Bu yöntem, araştırılan konunun uzmanlarından görüş ve değerlendirme alabilmek amacıyla, uzmanlara birbirinin devamı niteliğinde gönderilen anket turları sonuçlarına dayanan bir tahmin süreci olup, bir çeşit karar verme yöntemidir (Linstone ve Turoff 1975; Hsu ve Sandford 2007). Çalışmada Delphi yönteminin tercih edilme sebebi ise, bu yöntemin uzman görüşlerine dayanan bir karar verme süreci olması ve çalışmaya konu olan ölçütlerin belirlenmesi, gruplanması ve derecelendirilmesinde uzman kararlarına ihtiyaç duyulmasıdır. Literatürdeki birçok çalışmada afet sonrası geçici barınma/toplanma alanları yer seçim ölçütleri, önceki bir araştırma ya da mevzuattan hazır olarak alınarak kullanılmıştır. Ancak bu çalışma, öncelikli olarak literatürdeki ölçütler listelerinden ve ilgili mevzuattan yararlanarak geçici barınma alanlarının yer seçimi ve planlamasına dair ölçütler listesini yeniden oluşturmakta, bu listeyi yer seçim-planlama ve tasarım-uygulama ölçütleri olarak gruplamakta ve ölçütleri de önemlerine göre derecelendirmektedir. Tüm bu işlemleri yapabilmek için de uzman görüşlerine ihtiyaç duyulmaktadir.

Delphi yöntemi kapsamında çalışmada altı uzmanın görüşlerine başvurulmuştur. $\mathrm{Bu}$ uzmanların ikisi üniversitelerden, ikisi İzmir'deki belediyelerden, ikisi de AFAD'dan seçilmiştir. Bu üç aşama süresince değerlendirmeler dijital araçlar ile çevrim içi olarak yapılmış, uzmanlar bir araya gelmemiş, birbirlerinden etkilenmeleri önlenmiştir. Her etap sonucunda ortaya çıkan sonuçlar, uzmanlarla teker teker paylaşılmış ve yeni/ilave yorumları istenmiştir. Çalışma sonunda yer seçim-planlama ölçütleri açısından yeterlilikleri en iyi sağlayan alanda, yine Delphi yöntemi ile elde edilen tasarım-uygulama ölçütlerine dayanarak ve AFAD tarafından gerçekleştirilmiş örnek projelerin ana tasarım ölçütleri kullanılarak bir konteyner-kent vaziyet planı yapılmış, ilgili ölçütlerin uygunluğu uygulamalı olarak kontrol edilmeye çalışılmıştır.

Çalışma temel olarak beş bölümden oluşmaktadır. Girişi takip eden ikinci bölümde afet sonrası geçici barınma alanlarının yer seçimi ve planlamasına dair literatür incelenmiştir. Üçüncü bölümde afet sonrası geçici barınma alanlarının seçim, planlama ve tasarımında kullanılan ulusal ve uluslararası standartlar ortaya konmuştur. Dördüncü bölüm, Delphi Yönteminin uygulama etaplarına ayrılmıştır. Beşinci bölümde ise uygun özelliklere sahip bir bölgede barınma alanı tasarımı yapılırken nelere dikkat edilmesi gerektiği Seferihisar2 pilot çalışması özelinde açıklanmaya çalışılmıştır. Böylece bir geçici barınma alanının üst ölçekten alt ölçeğe kadar yer seçim, planlama ve tasarım ölçütleri ortaya konmaya çalışılmıştır. Son bölümde ise çalışmanın sonuçları tartışılmıştır.

\section{Afet Sonrası Geçici Barınma Alanlarına İlişkin Literatür Çalışmaları}

Bu çalışmada afet sonrası geçici barınma alanlarına dair literatür üç ana başlıkta incelenmiştir: İlk başlık, geçici barınma alanlarının yer seçimlerinin yapılmasına dair çalışmalardır. 
$\mathrm{Bu}$ çalışmalar hem kent ya da bölge ölçeğinde geçici barınma alanı olarak kullanılabilecek en uygun alanların bulunmasına, hem de var olan alanların ulusal ve uluslararası ölçütlere uygunluğunun analizine odaklanır. Bu konuda kullanılan çeşitli model ve yöntemler de bu bölümde anlatılmıştır. İkinci başlık afet sonrası geçici barınma alanlarının yer seçim ve planlama ölçütlerinin belirlenmesine yönelik çalışmalardır. Genelde çeşitli afet tipleri ve bölgesel şartlara göre oluşturulmuş ölçüt listelerinin derlemesi ya da yeni ölçüt setlerinin üretilmesini içerir. Son başlık ise afet sonrası geçici barınma birimlerinin tasarımına odaklanan çalışmalardır.

Afet sonrası geçici barınma alanlarının yer seçimine dair var olan literatüre bakıldığında, bu konunun afet yönetiminin en önemli konularından birisi olduğu, ulusal ve uluslararası çok sayıda çalışmaya konu olduğu görülmektedir. Dünyanın birçok ülkesinde afet sonrası acil/geçici barınma alanlarının seçimi ve planlanması için çalışmalar yapılmış ve bu konu ile ilgili çeşitli modeller oluşturulmuştur. Bu çalışmalar Tablo 1'de şu şekilde özetlenmiştir:

Tablo 1: Geçici barınma alanlarının seçimi ile ilgili yapılan önceki çalışmalar

\begin{tabular}{|c|c|c|c|c|}
\hline Yazar & Yil & Ülke & Problem & Yöntem \\
\hline Kongsomsaksakul vd. & 2005 & $\mathrm{ABD}$ & Sel/Geçici barınma alanı yer seçimi & $\begin{array}{l}\text { Genetik algoritma/ÇKKV (Çok } \\
\text { kriterli karar verme) }\end{array}$ \\
\hline Kelly & 2005 & Global & Geçici barınma alanı yer seçimi & Vaka analizi ve literatür taraması \\
\hline Yiğitcanlar vd. & 2005 & Türkiye & Geçici barınma alanı yer seçimi & Karar destek modeli \\
\hline Kar ve Hodgson & 2008 & $\mathrm{ABD}$ & Geçici barınma alanı yer seçimi & CBS tabanlı model \\
\hline El-Anwar vd. & 2009 & $\mathrm{ABD}$ & $\begin{array}{l}\begin{array}{l}\text { Kasırga/Geçici barınma alanı yer } \\
\text { seçimi }\end{array} \\
\end{array}$ & Matematiksel model \\
\hline Ablenado-Rosas vd. & 2009 & Meksika & Geçici barınma alanı yer seçimi & Matematiksel model \\
\hline Beyath & 2010 & Türkiye & Geçici barınma birimi tasarımı & Vaka analizi ve literatür taraması \\
\hline Youssef vd. & 2011 & Misir & Geçici barınma alanı yer seçimi & CBS tabanlı model \\
\hline Demirci ve Karakuyu & 2011 & Türkiye & Geçici barınma alanı yer seçimi & CBS tabanlı model \\
\hline Liu vd. & 2011 & $\mathrm{ABD}$ & Geçici barınma alanı yer seçimi & $\begin{array}{l}\text { CBS tabanlı model ve saha } \\
\text { çalışması }\end{array}$ \\
\hline Erkal ve Değerliyurt & 2011 & Türkiye & Geçici barınma alanı yer seçimi & Vaka analizi ve literatür taraması \\
\hline Li vd. & 2012 & $\mathrm{ABD}$ & $\begin{array}{l}\text { Kasırga/Geçici barınma alanı yer } \\
\text { seçimi }\end{array}$ & Matematiksel model \\
\hline Chu ve $\mathrm{Su}$ & 2011/2012 & Çin & $\begin{array}{l}\text { Deprem/Geçici barınma alanı yer } \\
\text { seçimi }\end{array}$ & AHP ve TOPSIS/ÇKKV \\
\hline Tong vd. & 2012 & Çin & Sel/Geçici barınma alanı yer seçimi & AHP ve CBS tabanlı model \\
\hline Cheng ve Yang & 2012 & Çin & Geçici barınma alanı yer seçimi & Matematiksel model \\
\hline Wei vd. & 2012 & Çin & Geçici barınma alanı yer seçimi & Matematiksel model \\
\hline Omidvar vd. & 2013 & İran & Geçici barınma alanı yer seçimi & ÇKKV ve CBS tabanlı model \\
\hline Karaman & 2014 & Türkiye & Geçici barınma alanı yer seçimi & CBS tabanlı model \\
\hline Karaman vd. & 2014 & Türkiye & Geçici barınma alanı yer seçimi & CBS tabanlı model \\
\hline Karaman ve Erden & 2014 & Türkiye & Geçici barınma alanı yer seçimi & AHP/ÇKKV ve CBS tabanlı model \\
\hline Rezaei & 2014 & Türkiye & Geçici barınma alanı yer seçimi & AHP/ÇKKV ve CBS tabanlı model \\
\hline Tucker vd. & 2014 & Sri Lanka & Geçici barınma birimi tasarımı & Vaka analizi \\
\hline Soltani vd. & $2014 / 2015$ & İran & Geçici barınma alanı yer seçimi & Delphi \\
\hline Bayram vd. & 2015 & Türkiye & Geçici barınma alanı yer seçimi & Matematiksel model \\
\hline Kilc1 vd. & 2015 & Türkiye & $\begin{array}{l}\text { Deprem/Geçici barınma alanı yer } \\
\text { seçimi }\end{array}$ & Matematiksel ve CBS tabanlı model \\
\hline Roh vd. & 2015 & İngiltere & Geçici barınma alanı yer seçimi & AHP/ÇKKV \\
\hline AFAD & 2016 & Türkiye & Geçici barınma alanı yer seçimi & Vaka analizi \\
\hline Uzut & 2016 & Türkiye & Geçici barınma birimi tasarımı & Vaka analizi ve literatür taraması \\
\hline Fan vd. & 2017 & Çin & Geçici barınma alanı yer seçimi & Matematiksel model \\
\hline Zhao vd. & 2017 & Çin & Geçici barınma alanı yer seçimi & Matematiksel model \\
\hline Şentürk ve Erener & 2017 & Türkiye & $\begin{array}{l}\text { Deprem/Geçici barınma alanı yer } \\
\text { seçimi }\end{array}$ & AHP/ÇKKV ve CBS tabanlı model \\
\hline Nasution & 2017 & Endonezya & Geçici barınma birimi tasarımı & Vaka analizi ve literatür taraması \\
\hline Junian ve Azizifar & 2018 & İran & $\begin{array}{l}\text { Deprem/Geçici barınma alanı yer } \\
\text { seçimi }\end{array}$ & AHP/ÇKKV ve CBS tabanlı model \\
\hline Trivedi & 2018 & Hindistan & Geçici barınma alanı yer seçimi & DEMATEL/ÇKKV \\
\hline Çınar vd. & 2018 & Türkiye & $\begin{array}{l}\text { Acil toplanma ve geçici barınma } \\
\text { alanı analizi }\end{array}$ & CBS tabanlı model \\
\hline Erdin vd. & 2018 & Türkiye & Acil toplanma alanı analizi & CBS tabanl1 model \\
\hline Zengin Çelik vd. & 2018 & Türkiye & Acil toplanma alanı analizi & CBS tabanlı model ve vaka analizi \\
\hline Bartusiak ve Said & 2018 & $\mathrm{ABD}$ & Geçici barınma birimi tasarımı & Vaka analizi \\
\hline Gerdan ve Şen & 2019 & Türkiye & $\begin{array}{l}\text { Acil toplanma ve geçici barınma } \\
\text { alanı analizi }\end{array}$ & Vaka analizi \\
\hline
\end{tabular}


Tablo 1'in devamı

\begin{tabular}{|l|l|l|l|l|}
\hline Yazar & Yll & Ülke & Problem & Yöntem \\
\hline Tuncel & 2019 & Türkiye & Geçici barınma birimi tasarımı & Vaka analizi ve literatür taraması \\
\hline İBB & 2020 & Türkiye & Geçici barınma alanı yer seçimi & CBS tabanlı model \\
\hline $\begin{array}{l}\text { Ömürgönülşen ve } \\
\text { Menten }\end{array}$ & 2021 & Türkiye & Geçici barınma alanı yer seçimi & Bulanık TOPSIS/ÇKKV \\
\hline Erdin vd. & 2021 & Türkiye & Acil toplanma alanı analizi & CBS tabanlı model \\
\hline Yalaz & 2021 & Türkiye & Geçici barınma birimi tasarımı & Vaka analizi ve literatür taraması \\
\hline
\end{tabular}

Tablo 1'de sunulan ve geçici barınma alanı yer seçimi/tasarımı odaklı çalışmalarda, afet sonrası problemlerin çözümü olarak kullanılan yöntemlerin farklılaştığı görülmektedir. Bu çalışmaların bazılarında tek bir çözüm/karar verme yöntemi kullanılırken, bazı çalışmalarda ise bütünleşik yöntemler/modeller önerilmiştir.

Afet sonrası geçici barınma alanlarının yer seçiminde önemli sayıda çalışma çeşitli matematiksel modellerden yararlanmıştır. Örnek olarak, Kongsomsaksakul vd. (2005), El-Anwar vd. (2009), Ablenado-Rosas vd. (2009), Li vd. (2012), Wei vd. (2012), Fan vd. (2017) ve Zhao vd. (2017) çalışmalarında, farklı ülkelerde çeşitli afetlerden etkilenen bir yerleşimde kurulabilecek geçici barınma alanlarının sayılarını ve yerlerini belirleyebilen matematiksel modeller ortaya koymuşlardır. Bayram vd. (2015) ve Kılcı vd. (2015) ise çalışmalarında bu modelleri Türkiye'deki farklı bölgeler için oluşturmuşlardır. $\mathrm{Bu}$ çalışmalarda konu alınan afetler değişkenlik göstermektedir. Örneğin Kongsomsaksakul vd. (2005) baraj kaynaklı sel riskini konu edinirken, El-Anwar vd. (2009) ve Li vd. (2012) kasırga riskini, Kılc1 vd. (2015) ise deprem riskini konu edinmiştir. Tüm bu modeller, belirlenen ölçütler çerçevesinde mevcut kentsel dokudan bağımsız olarak, geçici barınma alanlarının ideal potansiyel lokasyonunu bulmaya odaklanmıştır.

Afet sonrası planlama konusunu Coğrafi Bilgi Sistemleri (CBS) tabanlı yöntemler kullanarak inceleyen birçok ulusal ve uluslararası çalışma da vardır. Bunlara örnek olarak Kar ve Hodgson (2008), Youssef vd. (2011), Tong vd. (2012), Demirci ve Karakuyu (2011), Karaman (2014), Karaman vd. (2014), Rezaei (2014), Şentürk ve Erener (2017) ve Junian ve Azizifar (2018)'in çalışmaları sayılabilir. Bu çalışmalar da genel olarak yine bir pilot alan çalışması üzerinde belirlenen ölçütlere en uygun geçici barınma alanı yer seçimi konusuna odaklanmış olup, aralarında entegre model kurarak ÇKKV yöntemlerinden faydalananlar bulunmaktadır.

Literatürde var olan birçok çalışma ise en uygun geçici barınma yeri seçimi problemini çözmek adına ÇKKV yöntemlerinden yararlanmıştır. Chu ve Su (2011), Omidvar vd. (2013), Karaman ve Erden (2014), Roh vd. (2015), Trivedi (2018) ve Ömürgönülşen ve Menten (2021) bu çalışmalara örnek gösterilebilir. Afet sonrası geçici barınma alanlarının yer seçim ölçütlerinin belirlenmesine yönelik çalışmalar, konu hakkındaki literatürün bir başka ayağını oluşturmaktadır. Söz konusu geçici barınma alanların kent içinde doğru konumlandırılması ve farklı afet tiplerine, iklime ve sosyal yapıya uygun planlanması açısından bu çalışmalar oldukça önemlidir. Afet sonrası geçici barınma alanları için yer seçimi modelleri (bir kısmı ÇKKV kullanmıştır) öneren birçok çalışma, modele esas olacak yer seçim ölçütleri de önermektedir. Liu vd. (2011), Chu ve Su (2011, 2012), Cheng ve Yang (2012), K1lc1 vd. (2015) ve Omidvar vd. (2013) bu çalışmalara örnek olarak gösterilebilir. Bu çalışmaların temel amacı ölçüt listesi oluşturmak değildir ancak özellikle Omidvar vd. (2013)'ün çalışması görece kapsamlı bir ölçüt listesi de önerir. Kelly (2005) ve Soltani vd. (2014, 2015)'in çalışmaları tamamen ölçütlerin kapsamlı bir şekilde oluşturulmasına odaklanmış olup, Soltani vd. yöntem olarak Delphi tekniğini kullanmıştır. Bunun yanında bazı çalışmalar ise sadece ölçütlerin afet ve ülke özelliklerine göre belirlenmesine odaklanmıştır.

Türkiye'de de afet yönetimi ve afet sonrası toplanma/ barınma alanlarının belirlenmesi konusu özellikle son yıllarda daha yoğun şekilde çalışılır hale gelmiştir. Özellikle AFAD, bu konudaki çalışmalara öncülük etmektedir. AFAD’ın Ulusal Deprem Araştırma Programı (UDAP) kapsamında oldukça nitelikli çalışmalar üretilmiştir. Örnek olarak Karaman (2014)'ün İstanbul'daki Afet Sonrası Geçici Barınma Alanlarının Tespitine Yönelik Model Geliştirilmesi çalışması verilebilir. Bunun yanında AFAD’ın Şanlıurfa'daki geçici barınma projelerini anlattığı raporu (AFAD 2016) yine önemli bir kaynaktır. İstanbul Büyükşehir Belediyesi’nin geçici barınma ve toplanma alanlarının belirlenmesi (İBB 2020) projesi de yine kamu kurumlarının güncel çalışmalarına örnek gösterilebilir.

Kurumlar dışında çeşitli araştırmacıların da bu konuda çalışmaları vardır. Örneğin, Maral (2016), Çınar vd. (2018), Gerdan ve Şen (2019) AFAD tarafından ilan edilmiş acil toplanma ve geçici barınma alanlarının ölçütlere uygunluğunu analiz ederken; Erdin vd. (2018) toplanma alanlarının belirlenmesindeki ölçütlerin neler olduğunu tartışmıştır. Zengin Çelik vd. (2018) ve Erdin vd. (2021), toplanma alanlarının güvenlik ve ulaşım ölçütlerine uygunluğunu değerlendirirken, Yiğitcanlar vd. (2005) ise afet sonrası geçici yerleşim alanlarının yer seçiminde dikkat edilmesi gereken noktaları ve ölçütleri çeşitli yöntemler ile değerlendirmiş, bir karar destek modeli ortaya koymuştur. Erkal ve Değerliyurt (2011) ise konuyu tüm Türkiye ölçeğinde genel olarak ele almıştır.

Afet sonrası geçici yerleşim alanlarının tasarımındaki bir diğer önemli konu da geçici barınma alanlarının ve yaşam birimlerinin tasarımıdır. Bu konu, afetin tipine, coğrafya, iklimsel/ kültürel şartlara ve ekonomiye bağlı olarak oldukça değişkenlik gösterebilir. Tucker vd. (2014), Nasution (2017), Bartusiak ve Said (2018)'in geçici barınma birimi tasarımı üzerine çalışmaları bu konuda bir yurtdışı örneği iken, Beyatlı (2010), Uzut (2016), Tuncel (2019) ve Yalaz (2021) ise Türkiye'den örnekler olarak sayılabilir. 


\section{Afet Sonrası Barınma Alanlarının Seçimine ve Tasarımına dair Ulusal ve Uluslararası Standartlar}

Afet sonrası geçici barınma alanlarının yer seçiminde ve tasarımında kullanılan ulusal ve uluslararası standartlar şu şekilde özetlenebilir:

- AFAD'ın 04.11.2015 sayılı Geçici Barınma Merkezlerinin Kurulması, Yönetilmesi ve İşletilmesi Hakkında Yönergesi’ne (AFAD 2015) göre geçici barınma alanları aşağıdaki standartları sağlamalıdır:

o Yer Seçimi:

> Geçici barınma merkezlerinin, dış tehdit ve tehlikelere karşı korunabileceği, ayrıca kontrol ve koordinasyonun sağlanabileceği yerleşim yerlerine yeterli yakınlıkta olması,

> Kurulacağı alanın; elektrik, su ve kanalizasyonun şehir şebekesine bağlanmasına elverişli bölgelerde olmas1,

$>$ Nüfusun artması halinde yeni konteyner/çadır yerleştirilebilmesi amacıyla kapasite genişletmeye uygun olmas1,

Zemin etüdünün yapılmış olması,

$>$ Yağmur suyu havzasından en az 3 metre yüksekte olması,

$>$ Eğim derecesinin $\% 2$ ile $\% 6$ oranında olması,

> Hâkim rüzgârın düşünülmesi esastır.

○ Uygulama ve Diğer Standartlar:

> Okul, kreş, market, ibadet alanları, sağlık merkezleri, psiko-sosyal destek hizmet merkezi, spor tesisleri, çamaşırhane, içme suyu atık su arıtma tesisleri, oyun parkları, kurs alanları gibi tesislerin kurulumu için merkezin kapasitesine ve hizmet ölçeğine göre yer planlamasının yapılması,

> Ana yolların genişliğinin en az 15 metre, ara yolların genişliğinin ise en az 10 metre yapılması,

$>$ Konteyner/çadırlar ile giriş kapısı arasında en az 8 metre mesafe bulunması,

$>$ Merkezin girişine güvenlik kontrollü nizamiye yapılması,

$>$ Ana yollarının asfalt ya da parke taşı döşenmesi,

- Konteyner ve toplu çadırlar dışındaki çadırlarda tek bir ailenin barındırılması,

> Çadır ya da konteynerler için kişi başına düşen kapalı alanın 3.5-4.5m2 arasında olması,

$>$ Konteynerlerin yerden yüksekliğinin $30 \mathrm{~cm}$ olması,

$>$ Çadır ya da konteyner, tüm birimlere elektrik ulaştırılabilmesi,

$>$ Çadır ya da konteynerlerin iklim şartlarına ve yangın standartlarına uygun malzemeden üretilmesi, TSE normlarina uygun olması esastır.

- GABA Yer Seçimi Ölçütleri: AFAD İzmir, İyileştirme Şube Müdürlüğü tarafından afet sonrası geçici barınma alanı etütlerinin yapıldığı ve potansiyel alanların incelenmiş olduğu çalışma olup, AFAD (2015) yönergesi ile benzerlikler taşımaktadır (AFAD 2017):

○ Yer Seçimi:

> Yerleşim alanları içerisinde veya yerleşim alanlarına mümkün olduğu kadar yakın olmalı,

$>$ Yüzölçümü en az $35.000 \mathrm{~m}^{2}$ olmal,

D Elektrik, su ve kanalizasyonun şehir şebekesine bağlanmaya elverişli bölgelerde olmalı,

> Yeterli su olmalı (içmek, yemek pişirmek, sağlıklı koşullarda temizlenmek için),

$>$ Eğim en çok \%7'yi geçmemeli (tercihen $\% 2$ ile \%4 arasında olmali),

$>$ Toprağın cinsi kazıya ve suyu geçirmeye uygun olmalı ve drenajı sağlanmalı,

$>$ Ağır vasıtaların her türlü hava şartlarında ulaşabileceği bir yol olmalı, eğer bir yol inşa etmek gerekiyorsa toprak ve arazi tipi buna uygun olmal,

$>$ Fay hatt1, heyelan, sel baskını, kaya düşmesi gibi afet riski taşıyan yerler seçilmemeli,

> Yağmur mevsiminde birikmesi beklenen yağmur suyu havzasından en az 3 metre yukarıda olmalı,

> Bitki örtüsü ve mevcut kullanım durumu çadır ve konteyner kurulumuna engel olmamalı,

$>$ Tarımsal alan olmamasina dikkat edilmeli,

$>$ Mümkünse kamu arazisi olmalı.

- Uygulama ve Diğer Standartlar:

$>$ Halkın barınacağı yerlere hafif vasıtalar ulaşabilmeli,

> Hizmetlerin ve iç ulaşımın etkin ve verimli bir şekilde gerçekleşmesi sağlanmalı. 
- Sphere Projesi-Afetle Mücadelede Asgari Standartlar ve İnsani Yardım Sözleşmesi: Bir barınma alanının en ince ayrıntısına kadar ne gibi ölçütlere sahip olması gerektiğinin açıklanmış olduğu projedir. Bu ölçütler arasında afet sonrası geçici barınma alanında afetzedelere verilecek olan yiyeceklerin besin değerlerinden, alanın drenaj ve katı atık kontrolünün ne şekilde olması gerektiğine kadar her detay mevcut bulunmaktadır (Sphere Association 2018).

- Yer Seçimi/Stratejik Planlama:

> Seçilecek yer mevcut afetzede sayısını barındırmaya elverişli olmalıdır. Nüfusun artması ve ihtiyaç duyulması halinde alanı genişletme imkânı olmalıdır,

> Yerleşim yeri potansiyel tehlikelerin uzağında ve mevcut risklerin asgariye indirildiği güvenli alanlarda olmalıdır; deprem, toprak kayması, volkanik faaliyetler, sel ya da şiddetli rüzgarlar gibi doğal afet riskleri düşünülmelidir,

> Yerleşim yeri afetten kaynaklanan atıklardan uzakta olmalı, hastalık ya da kirlilik ile önemli vektör risklerine maruz olmamalıdır,

$>$ Şehirdeki zarar görmemiş temel hizmetlere erişim sağlanmalı; okullar, sağlık tesisleri, güvenli oyun alanları gibi yerlere ulaşım sağlanmalıdır,

> Yerleşim alanlarına erişim, yerel yol alt yapısının durumu ve ulaşım olanaklarına yakınlık, olası yardımın sağlanması sırasındaki kullanım (ağır vasıtaların alana ulaşabilmesi, gerekirse yapılabilmesi) gibi durumlar analiz edilmelidir,

$>$ Havalimanları, liman ve garlara yakınlık analizi yapılmalıdır,

> Yüzey suyu drenajı, arazi şartlarının da izin verdiği ölçüde yerinde yapılmalıdır. Yeterli drenaj ve erozyon kontrol önlemleri alınamadığı sürece eğim \% 5'in üzerinde olmamalı ya da yeterli drenaj sağlamak için \% 1 ' in altında olmamalıdır (ideal \%2-4),

> Sürekli su temini sağlamak için kentin su şebekesi öncelikli olmak üzere gerekli kaynaklara bağlantı sağlanmalıdır,

> Sürekli elektrik temini sağlamak için kent şebekesi öncelikli olmak üzere, güneş panelleri kurularak yerel elektrik enerjisi üretilmelidir,

$>$ Kent kanalizasyon ağlarına bağlantı varsa bu alanlar tercih edilmeli, yoksa yeterli fosseptik sistemi kurulmalıdır.

- Tasarım/Uygulama:

$>$ Alanın afet sonrası barınma fonksiyonlarına cevap verebilmesi için verimli işleyen ve ilgili standartları karşılayabilecek bir vaziyet planı tasarımı hazırlanmalıdır,

> Tüm barınakların temel hizmetlere güvenli erişiminin sağlanmalıdır,

> Yerleşim planı topoğrafyaya uygun, doğal çevreye en az zarar verecek şekilde yapılmalıdır,

$>$ Etkilenen tüm bireylerin kişi başına minimum kapalı alanı (konteyner/çadır) of $3.5 \mathrm{~m}^{2}$ olmalıdır,

> Yerleşim alanında kişi başına altyapı, yollar, sıhhi tesisat, okullar, işyerleri, su sistemleri, güvenlik/yardım tesisatı, marketler, depolama tesisleri, barınak yerleri dâhil en az $45 \mathrm{~m}^{2}$ düşmelidir. Toplu hizmetler yerleşim alanı dışında mevcut ise veya ek tesisler ile sağlanabiliyorsa minimum kullanılabilir yüzey alanı kişi başına $30 \mathrm{~m}^{2}$ olmalıdır,

> Yangın riski açısından yerleşim alanında her 300 metrede bir 30 metre yangın emniyet şeridi ayrılmalıdır. Yan yana binaların çökmesini önlemek için her hane arasında en az 2 metre (tercihen yapının iki katı yüksekliğinde) mesafe olmalıdır,

> İnşaat tasarımı iklim koşullarına uyumlu, rüzgar yüküne dayanıklı ve soğuk iklimlerde kar yükünü karşılıyor olmalıdır. Depreme karşı direnç ve zemin taşıma şartları teknik uzmanlar tarafından tespit edilmeli, toplu merkezler için yapıların ek yüklere ve artan doğal afet risklerine dayanıklılı̆̆ı, örneğin zemin, ara duvarlar, çatılar vs. değerlendirilmelidir,

> Su ve sanitasyon hizmetleri, sağlık tesisleri, okullar, rekreasyon alanları, ibadet yerleri, pazarlar ve geçim kaynağı faaliyetlerin sürekliliği için kullanılan hizmet alanlarına güvenli erişim sağlanmalıdır,

> Cinsiyet, farklı yaş grupları ve aileler arasında gerektiği kadar ayrı alan ve mahremiyet olmalı; alanda engelli çözümleri gerçekleştirilmelidir,

> Afetten etkilenen insanların aşina olduğu barınak çözümleri ve materyallerinin kullanılması, mümkünse kültürel, ekonomik ve sosyal olarak süründürülebilir materyaller teşvik dilmelidir,

> Optimal termal rahatlık, havalandırma ve koruma sağlamak için her mevsimde özel iklim koşullarına erişim olmalıdır,

> Mümkün yerlerde ağaç ve diğer bitkiler korunmalı, toprak erozyonu riski azaltılmalı ve gölge sağlanmalıdır,

> Alanda yenilenebilir enerji, geri dönüşüm, geri kazanım gibi sürdürülebilir uygulamalar hayata geçirilmelidir. 


\section{Delphi Yönteminin Uygulanması}

Delphi tekniğinin adını Eski Yunan'da geleceğe ilişkin kehanetlerde bulunan bir kâhinin yaşadığı yerden aldığı bilinmektedir. Delphi tekniği, 1950'li yıllarda ABD'de RAND firmasında çalışan Norman Dalkey ve Olaf Helmer adındaki iki araştırmacı tarafından özellikle askeri konulara ilişkin çıkarımda bulunmak amacıyla geliştirilmiş olup, yönetim, tıp, askeri konular, mühendislik, mimarlık, planlama, eğitim gibi çeşitli alanlardaki bilimsel araştırmalarda yaygın şekilde kullanılmaktadır. Delphi tekniği, araştırılan konunun uzmanlarından görüş ve değerlendirme alabilmek amacıyla, uzmanlara birbirinin devamı niteliğinde gönderilen anket turları sonuçlarına dayanan bir tahmin süreci olup, bir çeşit sistematik karar verme yöntemidir (Linstone ve Turoff 1975; Hsu ve Sandford 2007). Yöntem üç temel özelliğe sahiptir: katılımda gizlilik, grup tepkisinin istatiksel analizi ve kontrollü geri besleme (Dalkey ve Helmer 1963). Yöntemin önemli özelliklerinden biri, benzer durumlara ilişkin görüş farklılıklarının olduğu ortamlarda uzlaşma sağlama aracı ve karar almayı kolaylaştıran bir süreç olarak kullanılmasıdır. (Dalkey ve Helmer 1963; Şahin 2001). Yöntemin çıkış noktasında ortada ya fikir birliğinin sağlanamadığı bir konunun ya da konuyla ilgili bilgilerin tam olarak toparlanamadığı bir durumun olması beklenmekte olup, "belli bir konuda birçok görüş ve düşünce tek bir görüşten daha anlamlıdır" ilkesine dayanmaktadır (Yurt ve Kadıŏlu 2019).

Delphi tekniğin bazı avantajları ve kısıtlı yönleri olduğundan söz edilebilir. Avantajlı yöne örnek olarak ardışık anketlerin kullanılması ve analizlere ilişkin katılımcılara geri beslemede bulunulması, katılımcılara kendi görüşlerini ve diğer katılımcıların görüşlerini yeniden gözden geçirme firsatı verilmesi ve uzlaşmaya yönelik adım atılmasına olanak tanınması verilebilir. Ayrıca uzmanlar yüz yüze toplantı yapmalarına gerek kalmadan (zaman, mekân, maliyet, salgın, vd.), ardışık çevrimiçi çalışmalar boyunca anonim kalabilmekte ve grup baskısı azaltılabilmektedir. Yöntemin kısıtlı yönlerine örnek olarak katılımcıların çalışmaya başlangıçta katılıp, sonradan ayrılmaları, katılımda gizlilik ilkesinden fire verilmesi (istemeden de olsa kişi/grupları tanımlayıcı soru/cevap) ve uzlaşma için uğraşılırken fazlaca anket sorusu/turu üretilerek sürecin uzaması (bazen karmaşık hale gelmesi) verilebilir (Şahin 2001; Yurt ve Kadıoğlu 2019).

Buradan hareketle, çalışmanın bu aşamasında afet sonrası geçici barınma alanlarının seçimi ve değerlendirilmesinde yararlanılacak ölçütlerin belirlenmesine yönelik, uzmanların yapacağı öznel değerlendirmeye dayalı üç aşamalı bir Delphi paneli yürütülmüştür. Çalışmada altı uzmanın görüşlerine başvurulmuştur. Bu uzmanların ikisi üniversitelerden, ikisi İzmir'deki belediyelerden, ikisi de AFAD'dan seçilmiştir. Bu panelin ilk turu, geçici barınma alanlarının yer seçim-planlama ve tasarım-uygulama ölçütlerinin belirlenmesine; ikinci turu, belirlenen yer seçim ölçütlerinin gruplanmasına, önem ve ağırlıklarının atanmasına ayrılmıştır. Üçüncü tur ise belirlenen ölçütler ve ağırlıklar kullanılarak, İzmir ilinde AFAD tarafından belirlenmiş olan geçici barınma alanlarının puanlanması ve alanların tek tek yeterliliklerinin değerlendirilmesini kapsamaktadır.

Delphi panelinin ilk turunda, altlık olarak kullanılabilecek ham ölçütler listesi Soltani vd. (2015) in makalesindeki, yine bir Delphi paneli sonucu oluşturulmuş olan tablolardan alınmıştır. Bu liste Tablo 2'deki ölçütler sütununda görülebilir. Soltani vd. (2015)'in çalışmasında üretilen ölçütler listesine bakıldığında, hem geçici barınma alanlarının yerlerinin belirlenmesine, hem de bu alanda oluşturulacak geçici barınma birimlerinin tasarımına yönelik olduğu görülmüş̧ür. Ayrıca bazı ölçütlerin Türkiye şartlarında birleştirilebileceği de fark edilmiştir. Bu sebeple, uzman panelistlerden, ölçütleri "yer seçim-planlama" ya da "tasarım-uygulama" olarak sinıflandırmaları (her iki aşamada da bulunması gereken ölçütler belirtilmiştir) ve birbirine benzer ya da ilişkili olabilecekleri birleştirmeleri istenmiştir. Sınıflandırma çalışması sürecinin ne şekilde ilerlediği Tablo 2'de verilmiştir.

Tablo 2: Afet sonrası geçici barınma alanı ölçütleri belirleme/girdiler-Delphi 1.tur

\begin{tabular}{|r|l|l|}
\hline No & Ölçütler & Sınıflandırma \\
\hline 1 & Altyapı-mevcut/kurulacak & Yer seçim-Planlama / Tasarım-Uygulama \\
\hline 2 & Arazi drenaj1 & Tasarım-Uygulama \\
\hline 3 & Arazi eğimi & Yer seçim-Planlama \\
\hline 4 & Barınak tipi/modeli & Tasarım-Uygulama \\
\hline 5 & Barınma için öngörülen süre & Tasarım-Uygulama \\
\hline 6 & Bitki örtüsü & Yer seçim-Planlama \\
\hline 7 & Çevresel durum & Yer seçim-Planlama \\
\hline 8 & Çiftlik/hayvancılı alanları & Mevcut arazi kullanım ile benzer olduğu için birleştirilebilir \\
\hline 9 & Ekolojik durum & Çevresel durum ile benzer olduğu için birleştirilebilir \\
\hline 10 & Ekonomik boyut & Tasarım-Uygulama \\
\hline 11 & Elektrik altyapısı & Altyapp-mevcut yerine kullanılabilir \\
\hline 12 & Erişilebilirlik & Yer seçim-Planlama \\
\hline 13 & Erken uyarı sistemi & Tasarım-Uygulama \\
\hline 14 & Etki bölgesine yakınlık & Yer seçim-Planlama \\
\hline 15 & Etkilenen sayısı & Yer seçim-Planlama \\
\hline 16 & Fiziksel özellikler ve çevrenin durumu & Erişilebilirlik ve Çevresel durum ile benzer olduğu için birleştirilebilir \\
\hline 17 & Güvenlik ve koruma & Yer seçim-Planlama \\
\hline 18 & Hâkim rüzgâr yönü & İklim özellikleri ile benzer olduğu için birleştirilebilir \\
\hline 19 & Hidrolojik/meteorolojik tehlikeler & Yer seçim-Planlama \\
\hline 20 & İkincil tehlikelere uzaklık & Yer seçim-Planlama \\
\hline 21 & İklim özellikleri & Tasarım-Uygulama \\
\hline
\end{tabular}


Tablo 2'nin devamı

\begin{tabular}{|r|l|l|}
\hline No & Ölçütler & Sınıflandırma \\
\hline 22 & İletişim hizmetleri & Altyapı-kurulacak ile benzer olduğu için birleştirilebilir \\
\hline 23 & İnani yardım/kamusal hizmetler & Tasarım-Uygulama \\
\hline 24 & Jeolojik tehlikeler & Yer seçim-Planlama \\
\hline 25 & Kamuoyu/halkoyu & Tasarım-Uygulama \\
\hline 26 & Kirletici unsurlara uzaklık & Yer seçim-Planlama \\
\hline 27 & Kot/Rakım & Tasarım-Uygulama \\
\hline 28 & Kültür, gelenek ve nüfusun kompozisyonu & Kamuoyu/halkoyu ile benzer olduğu için birleştirilebilir \\
\hline 29 & Kültürel miras durumu & Yer seçim-Planlama \\
\hline 30 & Mevcut arazi kullanım & Yer seçim-Planlama \\
\hline 31 & Mülkiyet & Yer seçim-Planlama \\
\hline 32 & Sağlık tesislerine yakınlık & Yer seçim-Planlama \\
\hline 33 & Su kaynakları & Altyapı-mevcut yerine kullanılabilir \\
\hline 34 & Tarım alanları & Mevcut arazi kullanım ile benzer olduğu için birleştirilebilir \\
\hline 35 & Uygun büyüklük/kapasite & Yer seçim-Planlama / Tasarım-Uygulama \\
\hline 36 & Yağış & İklim özellikleri ile benzer olduğu için birleştirilebilir \\
\hline 37 & Yapı koruma standartları & Tasarım-Uygulama \\
\hline 38 & Yerel malzemeler & Tasarım-Uygulama \\
\hline 39 & Yol ağlarına yakınlık & Erişilebilirlik ile benzer olduğu için birleştirilebilir \\
\hline 40 & Zemin geçirgenliği & Yer seçim-Planlama \\
\hline
\end{tabular}

Uzmanların sınıflandırma çalışması sonrası yer seçim-planlama aşaması için altyapı-mevcut ölçütünün elektrik ve su altyapıları olarak ayrı ayrı değerlendirilmesi gerektiğine dair uzman görüşü dikkate alınarak 19 adet ölçüt belirlenmiştir. Tasarım-uygulama ölçütlerine ise Soltani vd. (2015)'in çalışmasında olmayan, ancak Sphere (2018) ve AFAD (2015)'in yayınladığı ölçütler listesinde olan "sürdürülebilirlik", "vaziyet planı (yerleşim tasarımı)" ve "yollar" eklenerek 16 ölçüt başlığı elde edilmiştir. Böylece Delphi panelinin ilk turu tamamlanmıştır. Bu noktada şunu hatırlatmak gerekir: Her uzman, ilgili ölçüte dair dikkat edilmesi gereken noktaları, notları veya sayısal değerleri not olarak tablolara eklemiştir. Bu notlar zaman zaman uzman görüşüne dayansa da bazı durumlarda AFAD, Sphere raporlarındaki kesinleşmiş veya yerel hükümlere uygun olarak oluşturulmuştur. Bu notların birleşmiş, netleşmiş ve ortak kabul edilmiş halleri Tablo 3 ve 5'te verilmiştir. Delphi panelinin 2. turu, belirlenen ölçütlerin gruplandırılmasını ve önem derecelerinin belirlenmesini için bir tablo oluşturulmasını amaçlar. Bu turda önem derecesi sıralaması, 3 puan en yüksek, 1 puan en düşük olacak şekilde yapılmıştır. Farklı uzmanların görüşlerinin ortalaması alınmış, bu ortalamalar, yine uzmanların uzlaşmaları dâhilinde tam sayıya yuvarlanarak kullanılmıştır. Bir diğer önemli nokta olarak ölçütlerin tanımı, dikkat edilmesi gereken noktalar ve sayısal değerler Tablo 3’ün tanım sütununa eklenmiştir.

Tablo 3: Afet sonrası geçici barınma alanı seçim ölçütleri belirleme/tanım ve önem derecesi-Delphi 2.tur

\begin{tabular}{|c|c|c|c|c|}
\hline Ana Kategori & No & Ölçütler & Tanım & $\begin{array}{l}\text { Önem } \\
\text { Derecesi } \\
(3>2>1)\end{array}$ \\
\hline \multirow{7}{*}{$\begin{array}{l}\text { Yerleşilebilirlik } \\
\text { analizi }\end{array}$} & 1 & Arazi eğimi & \%2-8 arası eğime sahip alanlar yerleşim açısından uygundur. & 3 \\
\hline & 2 & Bitki örtüsü & $\begin{array}{l}\text { Çalılar, çim ve ağaçlar gölge yarattıkları, tozu ve erozyonu önledikleri için, } \\
\text { alanların yeterli bitki örtüsüne sahip olmaları beklenmektedir. }\end{array}$ & 2 \\
\hline & 3 & Çevresel durum & Alanlar ekolojik/çevre koruma bölgeleri içinde/yakınında olmamalıdır. & 2 \\
\hline & 4 & Kültürel miras durumu & Alanlar kültürel/kentsel koruma bölgeleri içinde/yakınında olmamalıdır. & 2 \\
\hline & 5 & Mevcut arazi kullanım & $\begin{array}{l}\text { Alanın üzerinde mevcut ruhsatlı yapı olmaması; imar durumunun uygun olması; } \\
\text { tarım alanı, çiftlik/hayvancılık alanı olmaması gerekir. }\end{array}$ & 3 \\
\hline & 6 & Mülkiyet & $\begin{array}{l}\text { Alanın güncel mülkiyet durumu bilinmeli, kamu mülkiyetinde olanlar tercih } \\
\text { edilmelidir. }\end{array}$ & 3 \\
\hline & 7 & Zemin geçirgenliği & Zeminin geçirgenliğini ve yüzey suyunun drenajı önemli ölçütlerdendir. & 2 \\
\hline \multirow{8}{*}{$\begin{array}{l}\text { Altyap1/Hizmet } \\
\text { imkanları }\end{array}$} & 8 & Elektrik altyapısı & $\begin{array}{l}\text { Aydınlatma ve enerji ihtiyacının karşılanabilmesi için, alanların şehrin elektrik } \\
\text { altyapısına yakın olması önerilmektedir. }\end{array}$ & 2 \\
\hline & 9 & Erişilebilirlik & Alanların ulaşılabilir olması ve yol ağlarına yakınlık önemli faktörlerdendir. & 3 \\
\hline & 10 & Etki bölgesine yakınlık & $\begin{array}{l}\text { Alanların coğrafi dağılımı, afetzedelerin hızlıca erişebileceği biçimde } \\
\text { planlanmalıdır. }\end{array}$ & 2 \\
\hline & 11 & Etkilenen sayısı & $\begin{array}{l}\text { Alanların seçiminde olası bir afet durumunda etkilenecek bölge ve afetzede sayısı } \\
\text { dikkate alınmalıdır. Etkilenen nüfus büyüklüğ̈̈ ve bölgesi olarak ilçe düzeyi ele } \\
\text { alınmıştır. }\end{array}$ & 2 \\
\hline & 12 & Güvenlik ve koruma & $\begin{array}{l}\text { Afetzedelerin güvenlik ve korunma ihtiyaçlarını karşılamak için, alanların } \\
\text { polis/jandarma karakollarına uygun uzaklıkta yer seçmesi önerilmektedir. }\end{array}$ & 1 \\
\hline & 13 & $\begin{array}{l}\text { Sağlık tesislerine } \\
\text { yakınlık }\end{array}$ & Alanların sağlık merkezlerine yakın konumlanmasına dikkat edilmelidir. & 1 \\
\hline & 14 & Su kaynakları & $\begin{array}{l}\text { İçe suyu, kullanım suyu, yangın musluğu ve kanalizasyon hizmetlerinin } \\
\text { sağlanabilmesi için alanlar şehrin su ve kanalizasyon altyapısından bağlantı } \\
\text { alabilecek konumda olmalıdır. }\end{array}$ & 2 \\
\hline & 15 & $\begin{array}{l}\text { Uygun } \\
\text { büyüklük/kapasite }\end{array}$ & $\begin{array}{l}\text { Alanların fiziksel büyüklüğ̈̈, barındıracağı afetzede ve barınma birimi ile } \\
\text { altyapı/hizmetlerin verilebilecek büyüklükte olmalıdır. AFAD ölçütlerine göre } \\
\text { minimum alan büyüklüğü } 35000 \mathrm{~m}^{2} \text { olarak değerlendirilmiştir. }\end{array}$ & 3 \\
\hline
\end{tabular}


Tablo 3'ün devamı

\begin{tabular}{|c|c|c|c|c|}
\hline Ana Kategori & No & Ölçütler & Tanım & $\begin{array}{l}\text { Önem } \\
\text { Derecesi } \\
(3>2>1)\end{array}$ \\
\hline \multirow{4}{*}{$\begin{array}{l}\text { Afet riskini } \\
\text { azaltma }\end{array}$} & 16 & $\begin{array}{l}\text { Hidrolojik/meteorolojik } \\
\text { tehlikeler }\end{array}$ & $\begin{array}{l}\text { Alanlar dere yatakları, suyolları, su kanalları ve sele/tsunami'ye maruz } \\
\text { bölgelerden uzakta yer seçmelidir. }\end{array}$ & 3 \\
\hline & 17 & $\begin{array}{l}\text { İkincil tehlikelere } \\
\text { uzaklık }\end{array}$ & $\begin{array}{l}\text { Alanlar risk potansiyeli taşıyan yüksek binalardan, yanıcı ve patlayıcı } \\
\text { malzemelerden, tehlikeli kimyasallardan, radyoaktif maddelerden, yüksek } \\
\text { gerilim hatlarından; havaalanı, demiryolu, otoyol gibi afetin tekrarı olasılığında } \\
\text { ikincil tehlike yaratacak tüm unsurlardan uzakta yer seçmelidir. }\end{array}$ & 2 \\
\hline & 18 & Jeolojik tehlikeler & $\begin{array}{l}\text { Alanlar fay hatlarından, heyelan, çökme, kayma, zemin sıvılaşması, obruk, } \\
\text { bataklık gibi risk içeren bölgelerden uzakta yer seçmelidir. }\end{array}$ & 3 \\
\hline & 19 & $\begin{array}{l}\text { Kirletici unsurlara } \\
\text { uzaklık }\end{array}$ & $\begin{array}{l}\text { Alanlar insan sağlığı ve bulaşıcı hastalık riskini önlemek için kimya tesisi, } \\
\text { rafineri, çöplük, açık kanalizasyon, arıtma tesisi, mezbaha, ahır ve diğer kirlilik } \\
\text { yaratan unsurlardan uzakta yer seçmelidir. }\end{array}$ & 2 \\
\hline
\end{tabular}

Delphi panelinin 2. turunda ortaya çıkan nihai ölçüt listesi tüm uzmanlarca da onaylandıktan sonra, tüm barınma alanlarının ve ölçütlerin çakıştırıldığı listeye önem sırasına göre puan verilmiş, bu puanlama uzmanlara da onaylatılmıştır. İlgili ölçütü sağlayamayan geçici barınma alanı ise o ölçütten 0 puan almıştır. Bu puanlama, panelin 3. turunu oluşturmaktadır. Puanlamaya referans olan ve AFAD tarafından belirlenen 83 adet geçici barınma alanının ilçe düzeyinde sayıları Şekil 1'de verilmiştir. Bu şekle bakıldığında Çeşme, Kınık ve Kiraz ilçelerinde belirlenen herhangi bir alan olmadığ 1 da görülmektedir.

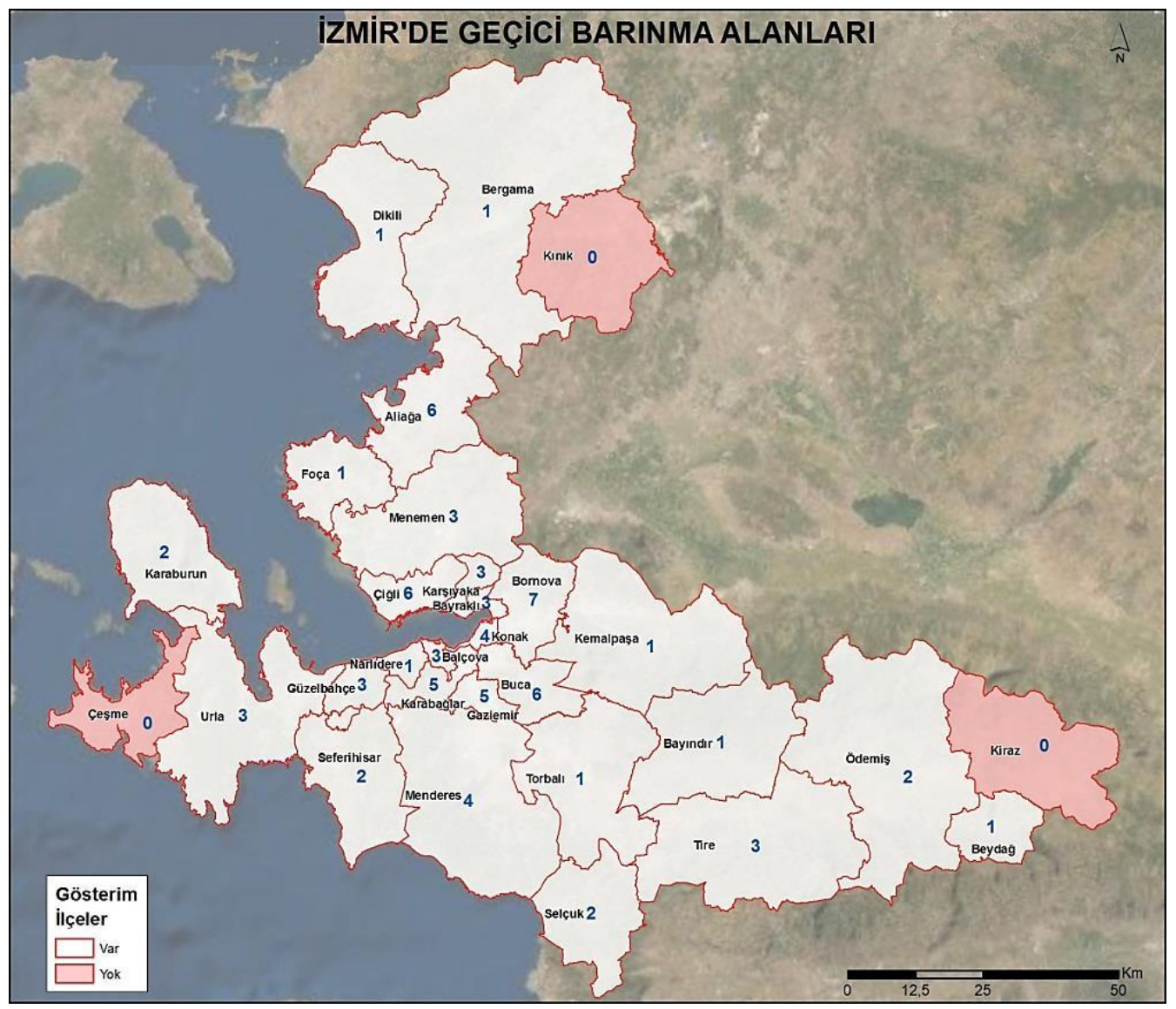

Şekil 1: Izmir'de ilçelere göre geçici barınma alanı sayıları

Bu turun neticesinde AFAD’ın belirlediği geçici barınma alanlarının uygunluğuna dair bir sıralama ortaya çıkmıștır. $\mathrm{Bu}$ sıralamaya göre, ölçütlere uyma puanı en yüksek alanların yer aldığı ilçeler Seferihisar ve Çiğli olmuştur. Seferihisar ilçesi içindeki "seferihisar2" alanı ise en uygun alan olarak belirlenmiştir. Bu alan "sağlık tesislerine yakınlık" ölçütü dışındaki tüm ölçütlerden tam puan almıştır. Bu alanı puan olarak takip eden "Seferihisar1" alanı ise "sağlık tesislerine yakınlık" ölçütüne ve "uygun büyüklük/ kapasite” ölçütlerini sağlamamaktadır. Seferihisar ve Çiğli ilçelerinin geçici barınma alanlarının puanlaması Tablo 4'te verilmiştir. İzmir ili için belirlenen 83 adet geçici barınma alanının puanlama tablosunun, baskıya uygun olmayacak kadar uzun olması sebebiyle sadece bu iki ilçe örneği paylaşıllmıştır. 
Tablo 4: Çiğli ve Seferihisar ilçelerindeki geçici barınma alanlarının puanlaması-Delphi 3.tur

\begin{tabular}{|c|c|c|c|c|c|c|c|c|c|c|c|c|c|c|c|c|c|c|c|c|c|}
\hline & Ölçüt No & 1 & 2 & 3 & 4 & 5 & 6 & 7 & 8 & 9 & 10 & 11 & 12 & 13 & 14 & 15 & 16 & 17 & 18 & 19 & Toplam \\
\hline \multicolumn{2}{|c|}{ Puan (Maks) } & 3 & 2 & 2 & 2 & 3 & 3 & 2 & 2 & 3 & 2 & 2 & 1 & 1 & 2 & 3 & 3 & 2 & 3 & 2 & 43 \\
\hline İlçe & Alan & & & & & & & & & & & & & & & & & & & & \\
\hline \multirow{6}{*}{ Çiğli } & cigli1 & 3 & 0 & 0 & 2 & 3 & 3 & 0 & 2 & 3 & 2 & 2 & 1 & 1 & 2 & 3 & 0 & 2 & 0 & 0 & 29 \\
\hline & cigli2 & 3 & 0 & 2 & 2 & 3 & 3 & 0 & 2 & 3 & 2 & 2 & 1 & 1 & 2 & 0 & 3 & 2 & 3 & 2 & 36 \\
\hline & cigli3 & 3 & 0 & 2 & 2 & 3 & 3 & 2 & 2 & 3 & 2 & 2 & 1 & 1 & 2 & 0 & 3 & 2 & 3 & 2 & 38 \\
\hline & cigli4 & 3 & 2 & 2 & 2 & 0 & 3 & 2 & 2 & 3 & 2 & 2 & 1 & 1 & 2 & 0 & 3 & 2 & 3 & 2 & 37 \\
\hline & cigli5 & 3 & 2 & 2 & 2 & 3 & 3 & 2 & 2 & 0 & 2 & 2 & 1 & 1 & 2 & 0 & 3 & 2 & 3 & 2 & 37 \\
\hline & cigli6 & 3 & 2 & 2 & 2 & 0 & 3 & 2 & 2 & 3 & 2 & 2 & 1 & 1 & 2 & 3 & 3 & 2 & 3 & 0 & 38 \\
\hline \multirow{2}{*}{ Seferihisar } & seferihisar1 & 3 & 2 & 2 & 2 & 3 & 3 & 2 & 2 & 3 & 2 & 2 & 1 & 0 & 2 & 0 & 3 & 2 & 3 & 2 & 39 \\
\hline & seferihisar2 & 3 & 2 & 2 & 2 & 3 & 3 & 2 & 2 & 3 & 2 & 2 & 1 & 0 & 2 & 3 & 3 & 2 & 3 & 2 & 42 \\
\hline
\end{tabular}

\section{Seferihisar Geçici Barınma Alanında Vaziyet Planı ve Konteyner Kent Tasarımı}

\subsection{Seferihisar 2 Alanının Özellikleri}

Delphi 3.tur paneli sonucu yapılan puanlama ile belirlenen alanda vaziyet planı tasarımına geçmeden önce, alana dair fiziksel bilgiler sıralanmıştır. Seferihisar İlçesi, Düzce Mahallesi, 147 ada 23 parselde bulunan, kamu mülkiyetinde olan alan (seferihisar2) $633.000 \mathrm{~m}^{2}$ büyüklüğündedir. Alan Adnan Menderes Havaalanı'na 29.8 km, Basmane Gar'ına 35.9 km, Alsancak Limanı'na 38 km, otoyol girişine ise 16.2 km; Seferihisar-İzmir yoluna 925 m, Seferihisar kavşağına 2.6 $\mathrm{km}$, Seferihisar ilçe merkezine $2.9 \mathrm{~km}$, Seferihisar 1 no'lu acil toplanma alanına $2.1 \mathrm{~km}, 5$ no'lu acil toplanma alanına ise $3.2 \mathrm{~km}$ uzaklıktadır (Şekil 2, Şekil 3).

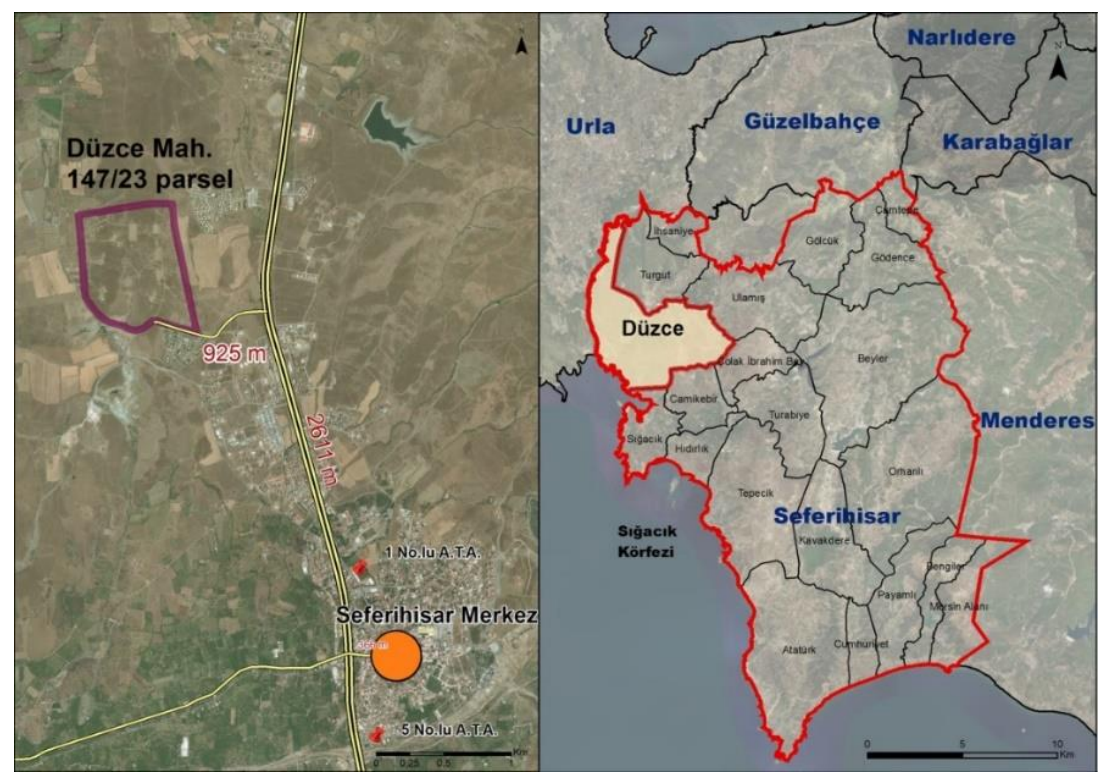

Şekil 2: Seferihisar2 alanının konumu

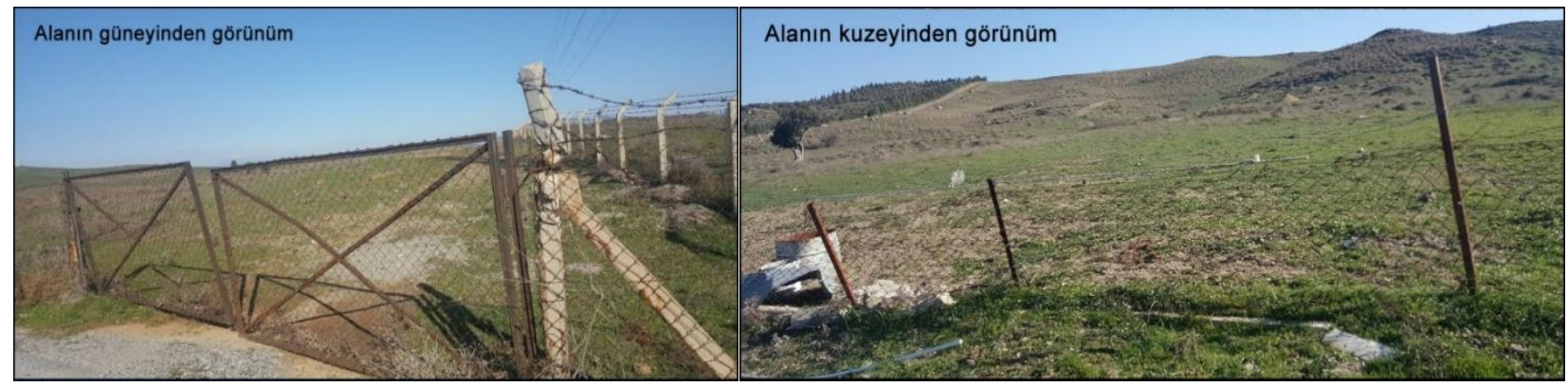

Şekil 3: Seferihisar2 alanından görünümler 
Alanda herhangi bir tarımsal faaliyete ve yoğun ağaç dokusuna rastlanmamıştır. Yakın çevresinde konut yerleşimleri ve ilçe merkezi yer aldığı için, temel altyapı unsurlarının yeterli olduğu gözlenmiştir. Alanın topoğrafyası incelendiğinde eğimin fazla olduğu bölümün arazinin küçük bir kısmını kapladığı, genelinin ise barınma alanı kurulmasına uygun olduğu görülmektedir. Ayrıca, eğim fazlalığı bulunan bölgenin arazinin orta kısmında olması, arazi içerisinde gerekli hafriyat ve dolgu işlemleri ile yerleşimi mümkün kılmaktadır. Alanda kotlar 5m'den başlayarak 37m kotuna kadar çıkmaktadır (Şekil 4). Alanın topoğrafik özellikleri, ileriye dönük vaziyet planı tasarımı çalışmaları için önemli bir veri olarak ele alınmıştır.

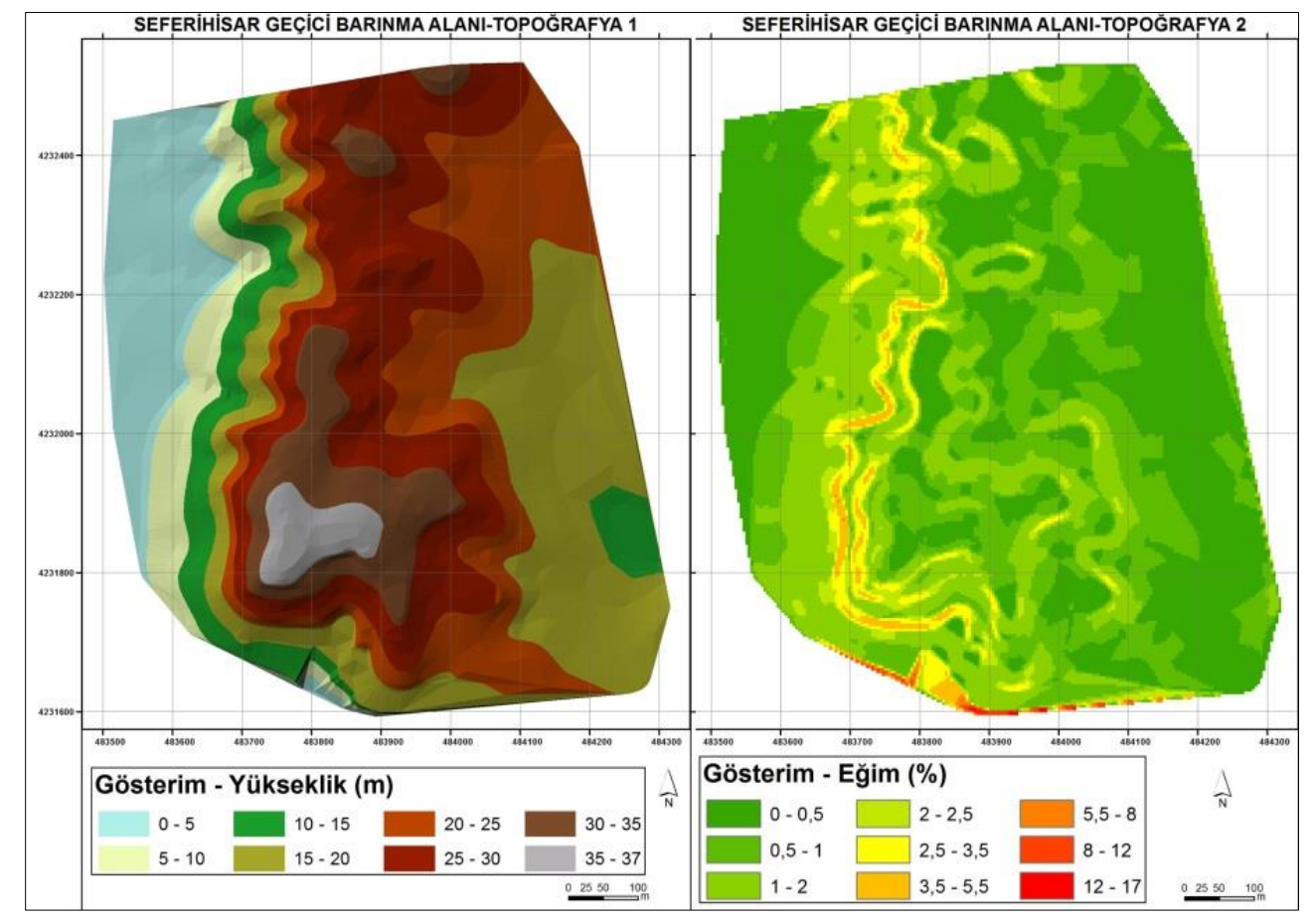

Şekil 4: Seferihisar2 alanının topoğrafik analizleri

\subsection{Seferihisar 2 Alanında Vaziyet Planı ve Konteyner Kent Tasarımı}

Bu bölümde çalışmanın önceki bölümlerinde tamamlanan analizler sonucu geçici barınma alanı olarak kullanılabileceği belirlenen Seferihisar2 alanında vaziyet planı ve tasarım adımlarına geçilmiştir. Geçici barınma alanının vaziyet planı ve barınma birimlerinin tasarımında da, yine Delphi panelinde elde edilmiş ve Tablo 5'te sıralanmış ölçütler tasarım girdileri olarak kullanılmıştır.

Uzmanların sınıflandırma çalışması sırasında, Soltani vd. (2015)'in çalışmasında olmayan, ancak Sphere (2018) ve AFAD (2015)'in yayınladığı rapor/yönergelerde yer alan başlıklar (Sürdürülebilirlik, Vaziyet planı (yerleşim tasarımı) ve Yollar) ve bazı ölçütlerin netleşmesi için ilave tanımlar ilgili tabloya eklenmiştir. Bu ek ölçüt/tanımlardan AFAD’ın 2015 tarihinde yayınladığı “Geçici Barınma Merkezlerinin Kurulması, Yönetimi ve İşletilmesi Hakkında Yönerge”de yer alanlar şöyle sıralanabilir:

- Yollar: ana yolların genişliğin en az 15 metre, ara yolların genişliğinin ise en az 10 metre olmalıdır,

- Yapı koruma standartları: konteynerlerin yerden yüksekliğinin $30 \mathrm{~cm}$ olmalıdır,

- Uygun büyüklük/kapasite: barınma birimi için kişi başına düşen kapalı alanın 3.5-4.5 $\mathrm{m}^{2}$ arasında olmalıdır.

Sphere Projesi (2018) kapsamında yararlanılan ölçüt/tanımlar da şunlardır:

- Sürdürülebilirlik: alanda yenilenebilir enerji, geri dönüşüm, geri kazanım gibi uygulamalar hayata geçirilmelidir,

- Vaziyet planı: Alanın afet sonrası barınma fonksiyonlarına cevap verebilmesi için verimli işleyen ve ilgili standartları karşılayabilecek bir vaziyet planı tasarımı hazırlanmalıdır,

- Uygun büyüklük/kapasite: yerleşim alanında kişi başına düşen alanın en az $45 \mathrm{~m}^{2}$ olmalıdır,

- Yapı koruma standartları: yangın riski açısından her 300 metrede bir 30 metre yangın emniyet şeridi ayrılmalı; yan yana binaların çökmesini önlemek için her hane arasında en az 2 metre (tercihen yapının iki katı yüksekliğinde) mesafe olmalıdır.

Tüm bu unsurların eklendiği nihai tasarım-uygulama ölçütler listesi Tablo 5'te görülebilir. 
Tablo 5: Afet sonrası geçici barınma alanı tasarım-uygulama ölçütleri ve tanımları

\begin{tabular}{|c|c|c|}
\hline No & Tasarım-Uygulama Ölçütleri & Tanım \\
\hline 1 & Altyapi-kurulacak & $\begin{array}{l}\text { a) Aydınlatma ve enerji ihtiyacının karşılanabilmesi için alanda elektrik altyapısı kurulmalıdır. b) İçme } \\
\text { suyu, kullanım suyu, yangın musluğu ve kanalizasyon hizmetlerinin sağlanabilmesi için alanda su ve } \\
\text { kanalizasyon altyapısı kurulmalılır. c) Alanda telefon ve diğer iletişim altyapı kurulmalıdır. }\end{array}$ \\
\hline 2 & Arazi drenaj 1 & Yüzey suyunun birikmesini önleyecek drenaj sistemi kurulmalıdır. \\
\hline 3 & Barınak tipi/modeli & $\begin{array}{l}\text { Seçilecek barınma biriminin maliyetinin düşük olması, farklı iklim koşullarına uyum sağlayabilmesi, } \\
\text { montajının kolay ve hızlı olabilmesi, tasarım/mekânsal esnekliğe/çeşitliliğe sahip olması gerekir. }\end{array}$ \\
\hline 4 & Barınma için öngörülen süre & $\begin{array}{l}\text { Geçici barınma için bir süre öngörülüyorsa, bu süre proje yönetim sürecinde değerlendirilmeli ve tüm } \\
\text { kararlar bu doğrultuda alınmalıdır. }\end{array}$ \\
\hline 5 & Ekonomik boyut & $\begin{array}{l}\text { Uygulama aşamasına geçilmeden önce maliyet analizi ve tedarik/satın alma/etaplama planları } \\
\text { tamamlanmalıdır. }\end{array}$ \\
\hline 6 & Erken uyarı sistemi & $\begin{array}{l}\text { Yaşanabilecek olası bir afet durumunda barınan nüfusu ve görevlileri uyararak yönlendirecek erken } \\
\text { uyarı sistemi kurulmalıdır. }\end{array}$ \\
\hline 7 & İklim özellikleri & Yağış, güneşlenme, hakim rüzgarlar gibi yerel iklim özellikleri analiz edilmelidir. \\
\hline 8 & İnsani yardım hizmetleri & $\begin{array}{l}\text { Alanda barınma ihtiyacının yanı sıra kamusal ve insani yardım hizmetleri de verileceğinden, bu } \\
\text { fonksiyonların karşılığı alan/tesislere karar verilmelidir. }\end{array}$ \\
\hline 9 & Kamuoyu/halkoyu & $\begin{array}{l}\text { Alanda barınacak nüfusun sosyal, kültürel ve demografik özellikleri bilinmeli ve tasarım sürecinde göz } \\
\text { önünde bulundurulmalıdır. }\end{array}$ \\
\hline 10 & Kot/Rakım & $\begin{array}{l}\text { Arazi kotlarının analizi, alanın fiziksel tasarımını ve vaziyet planı/barıma birimi uygulamalarını } \\
\text { etkilediğinden dolayı önemlidir. }\end{array}$ \\
\hline 11 & Sürdürülebilirlik & Alanda yenilenebilir enerji, geri dönüşüm, geri kazanım gibi uygulamalar hayata geçirilmelidir. \\
\hline 12 & Uygun büyüklük/kapasite & $\begin{array}{l}\text { Alanın yerleşilebilirliğe uygun net büyüklüğünün analizi, konumlandırılacak barınma ve diğer kamusal } \\
\text { kullanım birimlerinin sayısı/kapasitesine karar verilebilmesi için önemlidir. Ayrıca barınma birimi için } \\
\text { kişi başına düşen kapalı alanın 3.5-4.5 } \mathrm{m}^{2} \text { arasında olmasi; yerleşim alanında kişi başına düşen alanın ise } \\
\text { en az } 45 \mathrm{~m}^{2} \text { olması gerekir. }\end{array}$ \\
\hline 13 & Vaziyet planı & $\begin{array}{l}\text { Alanın afet sonrası barınma fonksiyonlarına cevap verebilmesi için verimli işleyen ve ilgili standartları } \\
\text { karşılayabilecek bir vaziyet planı tasarımı hazırlanmalıdır. }\end{array}$ \\
\hline 14 & Yapı koruma standartları & $\begin{array}{l}\text { Tün barınma ve kamusal kullanım birimleri TSE, Yangın Yönetmeliği ve Deprem Yönetmeliğine uygun } \\
\text { olmalıdır. Konteynerlerin yerden yüksekliği } 30 \mathrm{~cm} \text { olmalıdır, her birim arasında en az } 2 \text { metre (tercihen } \\
\text { yapının iki katı yüksekliğinde) mesafe olmalıdır. Yangın riski açısından her } 300 \mathrm{~m} \text { de bir } 30 \mathrm{~m} \text { yangın } \\
\text { emniyet şeridi ayrılmalıdır. }\end{array}$ \\
\hline 15 & Yerel malzemeler & Alandaki tüm uygulamalarda mümkün olduğunca yerel materyaller/malzemeler tercih edilmelidir. \\
\hline 16 & Yollar & $\begin{array}{l}\text { Alanın kendi içindeki erişilebilirliğinin sağlanması için yolların tasarımı/kademelenmesi önem } \\
\text { taşımaktadır. Ana yol genişliği en az } 15 \mathrm{~m} \text {, ara yol genişliği ise en az } 10 \mathrm{~m} \text { olmalıdır. }\end{array}$ \\
\hline
\end{tabular}

Geçici barınmayı sağlayacak olan birimlerin uyması gereken ölçütler arasında; maliyetinin düşük olması, farklı iklim koşullarına uyum sağlayabilmesi, montajının kolay ve hızlı olabilmesi, depolamasının kolay olması ve küçük bir alandan büyük faydalar elde edilebilmesi hızlıca sayılabilir. Bu noktada konteynerler zorlu iklim koşullarına ve yangına dayanım gösterebilmeleri, nakliye ve depolanmalarının kolay olması ve afetzedelerin ihtiyaç duyduğu mekânsal esnekliği sunabilme nitelikleri sebebiyle başlıca afet sonrası geçici barınma birimi olarak kullanılmaktadır. Dolayısıyla bu çalışmada da geçici barınma birimi olarak konteyner kullanımı tercih edilmiştir.

Konteyner planları yapılmadan, önceki örnekler incelenmiş ve barınması planlanan aile tiplerinin hangi ölçülere sahip konteynerleri kullanması gerektiği belirlenmiştir. Ayrıca konteyner planlarını oluşturma aşamasında TÜiK'in yapmış olduğu "İstatistiklerle Aile bültenlerinden" de (aile tipleri ve hane halkı sayıları) yararlanılmıştır (TÜIK 2019). Barınma birimlerinde kullanılacak olan konteynerler tasarlanırken $240 * 900 * 260 \mathrm{~cm}, 240 * 1200 * 260 \mathrm{~cm}, 300 * 700 * 260$ $\mathrm{cm}, 480 * 600 * 260 \mathrm{~cm}$ ve $480 * 1200 * 260 \mathrm{~cm}$ ölçülerinde olan konteynerler kullanılmıştır. Tuvalet ve mutfak birimleri, konteyner içinde değil, dışarıda bulunan ortak alanlarda çözülmüştür.

Çalışmanın son bölümünde, Delphi panelinden elde edilen tasarım-uygulama ölçütleri, Sphere Projesi ve AFAD tarafından Türkiye'de daha önce kurulmuş olan çadır kentler ile konteyner kentlerin mekânsal tasarımı referans alınarak (AFAD 2016), Seferihisar pilot yerleşim alanına bir vaziyet planı çalışması yapılmıştır (Şekil 5).

$\mathrm{Bu}$ vaziyet planı, kamusal kullanım alanlarını merkeze alarak, barınma alanlarııı bu ortak alanların çevresinde kurgulanmasını amaçlayan bir bölgelemeye sahiptir. Alanın ana yola bakan güney bölgesi otoparklara ve alanın idari merkezine ayrılmış, kayıt/ kabul, yönetim, jandarma birimleri, sağlık birimlerine ait birimlerin bir kısmı, lojistik ve yemekhane birimleri hemen otoparkın arkasına konumlandırılmışıı. Arazinin diğer bir alt bölgesi, merkezde yer alan ve ortak kullanım alanlarını içeren bölümdür. Bu alt bölgede okullar, yemekhane, ibadethane, sahra hastanesi, çarşı, kurs alanları, itfaiye, spor alanları ve çocuk oyun alanlarının yerleşimi yapılmıştır. Barınma alanları ise merkez ortak alanların çevresini sararak araziye yayılmıştır. Her bir birim arasında $3.5 \mathrm{~m}$ boşluk bırakılmış, barınma birimlerini oluşturan her bir mahalleyi çevreleyen ara yollar $11 \mathrm{~m}$, arazi çevresinde de $15 \mathrm{~m}$ 'lik ana yol tasarlanmıştır. Bu yol matrisi sayesinde alan içi ulaşımın sağlanması amaçlanırken, barınma alanının da nitelikli parselasyonu sağlanmıştır. 
Barınma birimleri mahallelerden oluşacak şekilde tasarlanmış olup, tuvalet, duş ve çamaşırhane birimleri de her bir mahallenin ortak alanında çözülmüştür. Ayrıca yalnızca ortak alanda değil her bir mahallede de yeşil alan bulunmasına önem verilmiştir.

Alanın fonksiyonel bölgelemesi ve vaziyet planı sonuçlandırılmadan önce uzmanların görüşleri alınarak vaziyet planının son hali verilmiştir. Tüm birimlerin yerleştirilmesi neticesinde İzmir-Seferihisar konteyner-kentinde 13.794 kişinin barınması, 1.056 kişinin de barınma merkezinde personel olarak çalışması planlanmıştır. Tüm ihtiyaç duyulan birimleri oluşturmak için toplamda 6.637 adet konteyner kullanılmıştır. Bu miktarın 4.936 tanesi barınma birimi konteynerleri için, 316 tanesi yönetim birimi konteynerleri için, geri kalan 1.385 tanesi de ortak kullanım alanlarında ihtiyaç duyulan konteyner birimleri için kullanılmıştır.

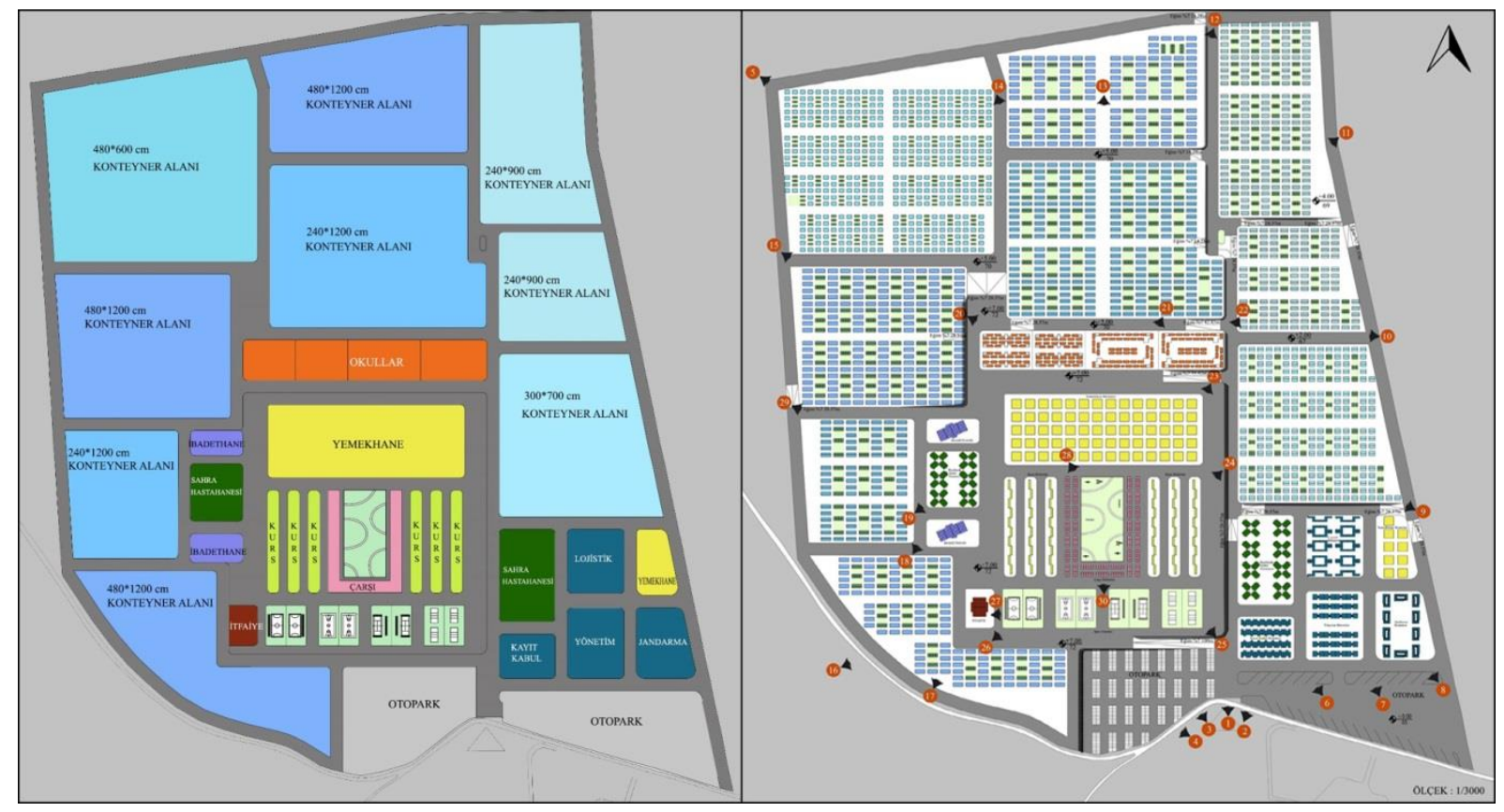

Şekil 5: Konteyner kent bölgeler şeması (solda), vaziyet planı (sağda)

\section{Sonuç ve Tartışma}

Yaşanan afetlerden sonra ortaya çıkan ihtiyaçlara bakıldığında barınma unsuru afet yönetimi açısından öncelikli bir konudur. Bu çalışma kapsamında afet sonrası geçici barınma alanlarının yer seçimi, planlaması ve tasarımına dair AFAD ve çeşitli akademik çalışmalarca ortaya konmuş olan bir dizi ölçütler listesi, Delphi yöntemi kullanılarak derlenmiş, detaylandırılmış ve derecelendirilmiştir.

Makalenin metodolojik açıdan literatürdeki önceki çalışmalar ile benzer yanı, ilgili araştırmalarda sıklıkla kullanılan ÇKKV yöntemlerinde ölçütlerin derecelendirilmesi/ağırlıklandırılması adımları stokhastik yöntemler ile yapılırken (Chu ve Su 2011; Omidvar vd. 2013; Karaman ve Erden 2014; Trivedi 2018; Ömürgönülşen ve Menten 2021), bu makalede Delphi turları üzerinden tamamlanmasıdır. Çalışmanın bu anlamda farklı yönü ise alternatiflerin değerlendirilmesinde diğer çalışmalar yine seçtikleri ÇKKV metodolojisine bağlı adımları uygularken, bu makalede aynı karar verme sürecinin bir puanlama tablosu ile hesaplanmasıdır (Delphi 3.tur/Tablo4).

Literatürdeki birçok çalışmada afet sonrası geçici barınma alanlarının yer seçimine dair ölçütler seti önceki bir araştırmadan ya da mevzuattan hazır olarak alınarak kullanılmıştır. Makalenin bu çalışmalardan ilk farkı, öncelikli olarak hazır bir ölçüt seti kullanmayarak, literatürdeki ölçütlerden ve ilgili mevzuattan yararlanarak yeni, daha kapsamlı ve Türkiye’ye özgü bir ölçüt seti önermesidir. Oluşan bu seti, yer seçim-planlama ve tasarım-uygulama ölçütleri olarak gruplaması ve önemlerine göre derecelendirmesi de çalışmanın bir diğer özgün katkısıdır. Literatürdeki birçok çalışma, sadece yer seçim-planlama ölçütlerini kullanarak afet sonrası geçici barınma alanlarının yer seçimini yapmayı önerir. Ancak tasarım-uygulama ölçütlerinin de işin içine katılması ile daha kapsamlı bir yer seçimi önerisinin ortaya çıkacağı açıktır.

Çalışmada oluşan ölçütler listesi ve tanımları, Türkiye şartlarına, özellikle de deprem kaynaklı afetlere uygun bir yer seçim ve planlama rehberi oluşturmaktadır. Oluşturulan ölçütler listesi literatürdeki yayınlardaki, ulusal ve uluslararası yönergelerdeki ölçütler listeleri ile karşılaştırılmış, ilgili tüm ölçütlerin listeye dâhil edilmesine dikkat edilmiştir. Elde edilen ölçütler listesinin önceki akademik ve kurumsal (AFAD, Sphere vb.) çalışmalarda ifade edilenlere göre avantajı, hem Türkiye şartlarına uygun olması, hem de listenin birçok ölçüt listesinden derlenmesinden dolayı kapsamlı olmasıdır. 
Çalışmanın ikinci aşamasında ise, AFAD tarafından İzmir için geçici barınma alanı olarak önerilmiş alanlar, yer seçimplanlama ölçütleri üzerinden uygunluk analizine tabi tutulmuştur. Böylelikle önerilen alanların hangi ölçütlere uyup uymadığı, en uygun alanların hangi ilçelerde bulunduğu ortaya konmaya çalışılmıştır. Analiz sonuçlarına göre birçok alan mülkiyet, arazi eğimi, altyapı-mevcut gibi temel ölçütleri sağlamakla beraber; birçoğu mevcutta yapılı çevre içerisinde bulunmaları (mevcut arazi kullanım), uygun büyüklük/kapasite ölçütünü karşılayamamaları ve diğer faktörler sebebi ile elenmiştir. İncelenen toplam 83 alandan hiçbirisi tüm ölçütleri karşılayamamaktadır. Sadece "seferihisar2" alanı sağlık tesislerine yakınlık dışındaki ölçütlere uygunluk göstermektedir. Bu kapsamda Seferihisar'da (seferihisar2), Delphi panelindeki uzman görüşleri, AFAD'ın 2015 yönergesi/saha çalışmaları ve Sphere Projesi gibi uluslararası çalışmalar da göz önünde bulundurularak oluşturulan tasarım uygulama ölçütlerini temel alan, pilot bir konteyner kent tasarımı yapılmıştır. Arazinin konteyner kent yerleşimine uyumlu vaziyet tasarımını yapabilmek için topoğrafik özellikleri analiz edilmiş ve arazi görsellerinden faydalanılmıştır. Vaziyet planı tasarımı insani yaşam şartlarına, aile durumlarına, sosyal ve diğer ihtiyaçlara cevap verecek şekilde konteyner tipleri belirlenerek organize edilmiştir. Böylece bir afet sonrası geçici barınma alanının üst ölçekten alt ölçeğe kadar yer seçim, planlama ve tasarım süreci ortaya konmaya çalışılmıştır.

Kuşkusuz olası bir afet durumunda İzmir kentinin ihtiyaç duyacağı geçici barınma alanı sayısı daha fazla, coğrafi dağılımı ise daha dengeli olmalıdır. Afet sonrası barınma alanlarının sadece konum olarak belirlenmesi, alanın kullanım stratejilerinin belirlenmesi açısından yeterli değildir. Her bir alanın kullanım senaryolarının hazırlanması ve bu senaryolara uygun olarak planlanması da oldukça önemlidir. Makalenin bir diğer kısıtlı yönünün Delphi panelinin 3. Turu olduğu düşünülmektedir. İzmir'deki 83 potansiyel alanın, ilgili ölçüt ve önem derecelerine göre puanlandığ1 (Tablo 4) yer seçim aşaması yerine, ÇKKV yöntemlerinden birisinin seçilerek kullanılması, çalışmanın yöntemine katkı sağlayabilir. Delphi ve ÇKKV yöntemlerinin entegre çalışacă̆ı bir model, karar verme sürecinin performansını artırılabilir. Bu nokta gelecek çalışmalarda dikkate alınmalıdır.

Buna ilaveten ileride yapılacak çalışmalarda; ölçütler listeleri farklı afet türlerine ve coğrafi/iklimsel bölgelere göre özelleştirilebilir. Böylece Türkiye’nin farklı coğrafi/ iklimsel/kültürel bölgeleri-kentleri için uygun barınma alanları tasarlanabilir. Bunun yanında, verilen alanın büyüklü̆̆̈u, eğimi, barınma birim sayısı gibi sayısal değerlere uygun olarak alanda vaziyet planı önerileri yapabilecek parametrik karar destek araçları üretilebilir.

\section{Kaynaklar}

Ablenado-Rosas J.H., Gao H., Alidaee B., Teng W., (2009), Allocation of emergency and recovery centres in Hidalgo, Mexico, International Journal Services Sciences, 2(2), 206-215.

AFAD, (2015), Geçici Barınma Merkezlerinin Kurulması, Yönetimi ve İşletilmesi Hakkında Yönerge, https://www.afad.gov.tr/ kurumlar/afad.gov.tr/2310/files/Gecici_Barinma_Merkezlerinin_Kurulmasi_Yonetimi_Isletilmesi_Yonerge.pdf [Erişim 12 Ocak 2021].

AFAD, (2016), Geçici Barınma Merkezlerinin Kurulumu, https://cdn2.beun.edu.tr/imid/egitim/gecici-barinma-merkezlerininkurulumu.pdf [Erişim 05 Ağustos 2021].

AFAD, (2017), GABA Yer Seçimi Kriterleri, AFAD İyileştirme Şube Müdürlüğü, İzmir.

AFAD, (2019), TAMP-İzmir, https://izmir.afad.gov.tr/tamp-izmir-2019 [Erişim 07 Aralık 2020].

AFAD, (2020), 30 Ekim 2020 Sisam Adasi Mw 6.6 Depremi Raporu, https://deprem.afad.gov.tr/downloadDocument?id=2065 [Erişim 18 Temmuz 2021].

Bartusiak J., Said H., (2018), Post-disaster interim shelter using manufactured housing units: Analysis of systems and supply in the United States, Construction Research Congress 2018: Safety and Disaster Management, doi: 10.1061/9780784481288.049.

Bayram V., Tansel B.Ç., Yaman H., (2015), Compromising system and user interests in shelter location and evacuation planning. Transportation Research, 72, 146-163.

Beyatlı C (2010), Acil Durum Barınaklarl ve Bir Barınak Olarak Acil Durum Konteynır Öneri Modeli, Yüksek Lisans Tezi, Trakya Üniversitesi, Edirne.

Cheng H., Yang X.K. (2012), A comprehensive evaluation model for earthquake emergency shelter, Proceedings of the 9th Asia Pacific Transportation Development Conference, ss. 412-422, doi: 10.1061/9780784412299.0050.

Chu J., Su Y., (2011), Comprehensive evaluation index system in the application for earthquake emergency shelter site, Advanced Materials Research, 156, 79-83.

Chu J., Su Y., (2012), The Application of TOPSIS Method in Selecting Fixed Seismic Shelter for Evacuation in Cities, Systems Engineering Procedia, 3, 391-397.

Çınar A.K., Akgün Y., Maral H., (2018), Afet sonrası acil toplanma ve geçici barınma alanlarının planlanmasındaki faktörlerin incelenmesi: İzmir-Karşlyaka örneği, Planlama, 28(2), 179-200.

Dalkey N.C., Helmer O., (1963), An experimental application of the Delphi method to he use of experts. Management Science, 9(3), 458-467.

Davis J., Lambert R., (2002), Engineering in Emergencies: A Practical Guide for Relief Workers, Second Edition, RedR/IT Publications, London, 728ss.

Dayanır H., (2019), Afet Sonrası Barınma Alanlarının Mekânsal Analizi ve Seferihisar Örneğinde Konteyner Kent Tasarımı, Yüksek Lisans Tezi, İzmir Kâtip Çelebi Üniversitesi, İzmir.

Demirci A., Karakuyu M., (2011), Afet yönetiminde coğrafi bilgi teknolojilerinin rolü, Doğu Coğrafya Dergisi, 9(12), 67-100.

El-Anwar O., El-Rayes K., Elnashai A., (2009), An automated system for optimizing post-disaster temporary housing allocation, Automation in Construction, 18, 8, 983-993. 
Erdin H.E., Zengin Çelik,H., Sılaydın Aydın M.B., Partigöç N.S., (2018), Afet ve acil durumlar sonrası halkın toplanma alanlarına ilişkin kriterlerin belirlenmesi ve değerlendirilmesi yönteminin oluşturulması, İzmir kenti örneği, AFAD-UDAP Çalışması, Proje No: UDAP-G-16-08, Ankara.

Erdin H.E., Sılaydın Aydın M.B., Partigöç N.S., Zengin Çelik H., Palazca A., Horoz, Ç., (2021), Kent içi yol kademelenmesinin afet durumunda toplanma alanlarının erişilebilirliğine etkisi açısından irdelenmesi, Academic Platform Journal of Engineering and Science, 9-1, 103-111.

Erkal T., Değerliyurt M., (2011), Türkiye'de afet yönetimi, Doğu Coğrafya Dergisi, 14(22), 147-164.

Fan C., Zhai G., Zhou S., Zhang H., Qiao P., (2017), Integrated Framework for Emergency Shelter Planning Based on Multihazard Risk Evaluation and Its Application: Case Study in China, Natural Hazards Review, 18(4), 05017003, doi: 10.1061/(ASCE)NH.1527-6996.0000253.

Gerdan S., Şen A., (2019), Afet ve acil durumlar için belirlenmiş toplanma alanlarının yeterliklerinin değerlendirilmesi: İzmit örneği, İDEALKENT, 10(28), 962-983.

Hsu C., Sandford B., (2007), The Delphi Technique: Making Sense of Consensus, Practical Assessment, Research and Evaluation, 12, 10, doi: doi.org/10.7275/pdz9-th90.

İB (2020), IBB toplanma ve geçici barınma alanları'nı belirledi, https://www.ibb.istanbul/arsiv/36384/ibb-toplanma-ve-gecicibarinma-alanlarini-bel [Erişim 12A ğustos 2021].

Junian J., Azizifar V., (2018), The Evaluation of Temporary Shelter Areas Locations Using Geographic Information System and Analytic Hierarchy Process, Civil Engineering Journal, 4(7), 1678-1688.

Kar B., Hodgson M.E., (2008), A GIS-based model to determine site suitability of emergency evacuation shelters, Transactions in GIS, 12(2), 227-248

Karaman H., (2014), İstanbul'da Afet Sonrası Geçici Barınma Alanlarının Tespitine Yönelik Model Gelişstirilmesi, AFAD Ulusal Deprem Araştırma Programı Projesi, AFAD-UDAP-Ç-12-03, https://deprem.afad.gov.tr/icerik?id=10\&menuId=100.

Karaman H., Erden T., (2014), Net earthquake hazard and elements at risk (NEaR) map creation for city of Istanbul via spatial multi-criteria decision analysis. Natural Hazards. 73, 685-709.

Karaman H., Rezaei S., Kalkan K., Konukçu B.E., Erden T., (2014), Afet Sonrası En Uygun Geçici Barınma Alanlarının CBS ile Tespiti, V. Uzaktan Algılama ve Coğrafi Bilgi Sistemleri Sempozyumu (UZAL-CBS 2014), 14-17 Ekim, İstanbul.

Kelly C., (2005), Checklist-based Guide to Identifying Critical Environmental Considerations in Emergency Shelter Site Selection, Construction, Management and Decommissioning, Office for the Coordination of Humanitarian Affairs, Geneva, 34ss.

Kılc1 F., Kara B.Y., Bozkaya B., (2015), Locating temporary shelter areas after an earthquake: a case for Turkey, European Journal of Operational Research, 243, 323-332.

Kongsomsaksakul S., Yang C., Chen A., (2005), Shelter location-allocation model for flood evacuation planning. Journal of the Eastern Asia Society for Transportation Studies, 6, 4237-4252.

Li A.C.Y., Nozick L., Xu N., Davidson R., (2012), Shelter location and transportation planning under hurricane conditions, Transportation Research, 48, 715-729.

Linstone H.A., Turoff M., (1975), The Delphi method: techniques and applications, Addison-Wesley, Reading, MA, 620ss.

Liu Q., Ruan X., Shi P., (2011), Selection of emergency shelter sites for seismic disasters in mountainous regions: Lessons from the 2008 Wenchuan Ms 8.0 Earthquake, China, Journal of Asian Earth Sciences, 40(4), 926-934.

Maral H., (2016), Afet sonrası geçici yerleşim yerlerinin planlanmasında üst ölçekli planlama: Karşıyaka örneği, Yüksek Lisans Tezi, Gediz Üniversitesi, İzmir.

Nasution, İ., (2017), Doğal Afetler Sonrasında Kullanılacak Geçici Barınak Tasarımı Üzerine Bir Çalışma: Endonezya - Sinabung Örneği, Doğal Afetler ve Çevre Dergisi, 3(2) , 93-111.

Omidvar B., Baradaran-Shoraka M., Nojavan M., (2013), Temporary site selection and decision making methods: a case study of Tehran, Iran, Disasters, 37(3), 536-553.

Ömürgönülşen M, Menten C., (2021), Bulanık TOPSIS Yöntemi ile Ankara İli İçin Olası Afet Sonrası Geçici Barınma Alanlarının Seçimi, Doğal Afetler ve Çevre Dergisi, 7(1), 159-175.

Rezaei S., (2014), Developement of a decision support model for the optimum shelter location following a disaster, MSc. Thesis, Istanbul Technical University, Graduate School of Science, Engineering and Technology, İstanbul, Turkey.

Roh S., Pettit S., Harris I., Beresford A., (2015), The pre-positioning of warehouses at regional and local levels for a humanitarian relief organisation, International Journal of Production Economics, 170(2015), 616-628.

Soltani A., Ardalan A., Darvishi Boloorani A., Haghdoost A., Hosseinzadeh-Attar M.J., (2014), Site selection criteria for sheltering after earthquakes: a systematic review, PLOS Currents Disasters, 2014,6, doi: 10.1371/currents.dis.17ad1f98fb85be80785d0a81ced6a7a6.

Soltani A, Ardalan A, Darvishi Boloorani A, Haghdoost A, Hosseinzadeh-Attar M.J., (2015), Criteria for Site Selection of Temporary Shelters after Earthquakes: a Delphi Panel, PLOS Currents Disasters, 7, doi: 10.1371/currents.dis.07ae4415115b4b3d71f99ba8b304b807.

Sphere Association (2018), The Sphere Handbook: Humanitarian Charter and Minimum Standards in Humanitarian Response, Fourth edition, Geneva, Switzerland, http://www.sphereproject.org/handbook/[Erişim 25 Ağustos 2020].

Şahin A.E., (2001), Eğitim araştırmalarında Delphi tekniği kullanımı, Hacettepe Üniversitesi Eğitim Bilimleri Dergisi, $20,215-220$.

Şentürk E., Erener A., (2017), Determination of Temporary Shelter Areas in Natural Disasters By GIS: A Case Study for Gölcük/ Turkey, International Journal of Engineering and Geosciences, 2(3), 84-90.

Tong Z., Zhang J., Liu X., (2012), GIS-based design of urban emergency shelter in Songbei Harbin, In Recent advances in computer science and information engineering, Springer, Berlin, Heidelberg, ss.617-622.

Trivedi A., (2018), A multi-criteria decision approach based on dematel to assess determinants of shelter site selection in disaster response. International Journal of Disaster Risk Reduction, 31, 722-728.

Tucker S., Gamage A., Wijeyesekera C., (2014), Some design aspects of sustainable post-disaster housing, International Journal of Disaster Resilience in the Built Environment, 5(2), 163-181. 
Tuncel A., (2007), Mobil konutlarda iç mekân organizasyonu ve mobil mekânların tarihsel gelişim süreci, Yüksek Lisans Tezi, Mimar Sinan Güzel Sanatlar Üniversitesi, Fen Bilimleri Enstitüsü, İstanbul.

TÜIK, (2019), Istatistiklerle Aile, https://tuikweb.tuik.gov.tr/PreHaberBultenleri.do?id=33730 [Erişim 5 Ekim 2020].

Uzut H., (2016), Deprem sonrası geçici barınma ünitelerinin görsel ve yarışma proje örnekleri üzerinden incelenmesi, Yüksek Lisans Tezi, Mimar Sinan Güzel Sanatlar Üniversitesi, Fen Bilimleri Enstitüsü, İç Mimarlık Ana Bilim Dalı, İstanbul.

Wei L., Li W., Li K., Liu H., Cheng L., (2012), Decision support for urban shelter locations based on covering model, Procedia Engineering, 43, 59-64.

Yalaz E.T., (2021), Afet sonrasında yapılan geçici konut örneklerinin ve yapım sistemlerinin değerlendirilmesi, Yüksek Lisans Tezi, Süleyman Demirel Üniversitesi, Isparta.

Yiğitcanlar T., Bolposta R., Yankaya U., Kınac O., Baradan B., Bektaş B., (2005), Afet Sonrası Geçici Yerleşim Alanlarının Tasarımında Stratejik Seçim Yaklaşımı, Planlama, 2005(2), 89-100.

Yurt S., Kadığlu H., (2019), Delfi Uzlaşı Tekniğinin Hemşirelikte Kullanımı, Hemşirelikte Eğitim ve Araştırma Dergisi, 16(1), 4853.

Youssef A.M., Pradhan B., Hassan A.M., (2011), Flash Flood Risk Estimation Along the St. Katherine Road, Southern Sinai, Egypt Using GIS Based Morphometry and Satellite Imagery, Environmental Earth Sciences, 62(3), 611-623.

Zengin Çelik H.Z., Sılaydın Aydın M.B., Partigöç N.S., Erdin H.E., (2018), Deprem riskleri bağlamında toplanma alanlarının güvenlik kriterleri temelinde değerlendirilmesi: Bayraklı (İzmir) örneği, ISHAD 2018, $2^{\text {nd }}$ International Symposium on Natural Hazards and Disaster Management, Sakarya.

Zhao L., Li H., Sun Y., Huang R., Hu Q., Wang J., Gao F., (2017), Planning emergency shelters for urban disaster resilience: an integrated location-allocation modeling approach, Sustainability, 9(11), 2098, doi: doi.org/10.3390/su9112098. 